\title{
Climate Change Impacts on Global Agriculture
}

\author{
Alvaro Calzadilla ${ }^{a, b, *}$, Katrin Rehdanz $^{a, c}$, Richard Betts $^{d}$, Pete Falloon ${ }^{d}$, Andy Wiltshire ${ }^{d}$ \\ and Richard S.J. Tol ${ }^{e, f, g}$
}

\author{
${ }^{a}$ Kiel Institute for the World Economy, Kiel, Germany \\ ${ }^{b}$ International Max Planck Research School on Earth System Modelling, Hamburg, Germany \\ ${ }^{c}$ Christian-Albrechts-University of Kiel, Department of Economics, Kiel, Germany \\ ${ }^{d}$ Met Office Hadley Centre, Exeter, United Kingdom \\ ${ }^{e}$ Economic and Social Research Institute, Dublin, Ireland \\ ${ }^{f}$ Institute for Environmental Studies, Vrije Universiteit, Amsterdam, The Netherlands \\ ${ }^{g}$ Department of Spatial Economics, Vrije Universiteit, Amsterdam, The Netherlands
}

Draft Version, April, 2010

\begin{abstract}
Based on predicted changes in the magnitude and distribution of global precipitation, temperature and river flow under the IPCC SRES A1B and A2 scenarios, this study assesses the potential impacts of climate change and $\mathrm{CO}_{2}$ fertilization on global agriculture. The analysis uses the new version of the GTAP-W model, which distinguishes between rainfed and irrigated agriculture and implements water as an explicit factor of production for irrigated agriculture. Future climate change is likely to modify regional water endowments and soil moisture. As a consequence, the distribution of harvested land would change, modifying production and international trade patterns. The results suggest that a partial analysis of the main factors through which climate change will affect agricultural productivity lead to different outcomes. Our results show that global food production, welfare and GDP fall in the two time periods and SRES scenarios. Higher food prices are expected. Independently of the SRES scenario, expected losses in welfare are marked in the long term. They are larger under the SRES A2 scenario for the 2020s and under the SRES A1B scenario for the 2050s. The results show that countries are not only influenced by regional climate change, but also by climate-induced changes in competitiveness.
\end{abstract}

Keywords: Computable General Equilibrium, Climate Change, Agriculture, Water Resources, River Flow

JEL Classification: D58, Q54, Q17, Q25

\footnotetext{
* Corresponding author: Kiel Institute for the World Economy, Hindenburgufer 66, 24105 Kiel, Germany. Tel.: 494318814 401; fax: 494318814 500. E-mail address: alvaro.calzadilla@ifw-kiel.de
} 


\section{Introduction}

Water is essential. The impact of climate change on water resources is therefore one of the most important reasons for concern about unabated greenhouse gas emissions. However, while many studies have focussed on the natural science aspects of water availability, the human response is crucially important: Adaptation could potentially alleviate the impact of falling water resource but maladaptation may exacerbate the situation. Adaptation, including adaptation to changing water resources, is often studied at the local scale. However, farmers are the biggest global water users and farmers operate, directly or indirectly, at the world market for agricultural products. This paper therefore looks at the impacts of climate-changeinduced changes in water resources on agriculture in the context of international trade.

Current observations and climate projections suggest that one of the most significant impacts of climate change is likely to be on the hydrological system, and hence on river flows and regional water resources (Bates et al. 2008; Strzepek and McCluskey 2007). Principal climate variables affecting water availability are precipitation, temperature and potential evaporation. Precipitation is the source of all freshwater resources and determines the level of soil moisture, which is essential in the formation of runoff and hence river flow. ${ }^{1}$ Soil moisture is determined not only by the volume and timing of precipitation, but also by a complex interaction and feedbacks with evaporation and temperature (IPCC 2001b).

By itself, an increase in precipitation would increase soil moisture. However, even with higher precipitation, surface runoff may decrease in some river basins due to greater evaporation in a warmer atmosphere (IPCC 2001a). Temperature is particularly important in snow-dominated regions, determining the timing of snowmelt and thus the seasonality of available water. In regions with little or no snowfall, surface runoff is much more dependent on rainfall than on temperature (Bates et al. 2008; Barnett et al. 2005).

Climate model simulations suggest that global average precipitation will increase as global temperature rise. As a result, global water availability is expected to increase with climate change. However, large regional differences are expected. At high latitudes and in some wet tropical areas, river flow and water availability are projected to increase. An

\footnotetext{
${ }^{1}$ Runoff and river flow are closely related and its distinction can be vague. Runoff is the amount of precipitation which flows into rivers and streams following evaporation and transpiration by plants, usually expressed as units of depth over the area of the catchment. River flow or streamflow is the water flow within a river channel, usually expressed as a rate of flow past a point (IPCC 2001a).
} 
opposite trend is projected for some dry regions at mid-latitudes and in the dry tropics (Falloon and Betts 2006; Bates et al. 2008). In many regions, the positive effects of higher annual runoff and total water supply are likely to be offset by the negative effects of changes in precipitation patterns, intensity and extremes, as well as shifts in seasonal runoff. Therefore, the overall global impacts of climate change on freshwater systems are expected to be negative (Bates et al. 2008).

Precipitation intensity and variability are expected to rise under a warmer climate, increasing the risks of flooding and drought in many regions. Alcamo et al. (2007a) estimated an increase in future average water availability in Russia, but also a significant change in the frequency of high and low runoff events; which eventually change the positive effect of more water supply. In many of the main crop areas in Russia, changes in the frequency of extreme climate events could double the frequency of food production shortfalls in the 2020s and triple in the 2070s.

In addition, the projected increase in precipitation intensity is expected to exacerbate water pollution and produce adverse effects on surface and groundwater quality as well as increase the risk of soil erosion (Boxall et al. 2009; Falloon and Betts 2009; Macleod et al. 2010). Similarly, more frequent and intense droughts are expected to spread water stress and increase land degradation, increasing the risk of water and food shortages. Changes in precipitation patterns may also affect groundwater recharge rates (Bates et al. 2008).

Shifts in the amount and seasonality of river flows caused by changes in monthly precipitation and temperature are expected to impact aquatic and riparian ecosystems and modify the availability of water for irrigation, industrial and domestic use. Barnett et al. (2005) projected a decline in the water stored in glaciers and snow cover in the tropical Andes and in many Asian mountain regions, affecting adversely river flow and water supply during the long dry seasons. Changes in river flow would also affect the capacity of hydroelectric power generation.

In addition to affecting water supply systems, climate change will also affect water demand. Higher temperatures and changes in precipitation patterns are expected to increase irrigation water demand for crops. Based on a revised SRES A2 scenario, Fischer et al. (2007) estimated an increase in global irrigation water requirements of 45 percent between 2000 and 2080. Irrigation water requirements were projected to increase by around 50 percent in developing regions and 16 percent in developed regions. Fischer et al. (2007) found that two-thirds of the increases in irrigation water requirements were related to an increase in the average daily requirements caused by warming and changed precipitation patterns; and one- 
third was related to the extended crop calendars in temperate and sub-tropical zones. In turn, irrigation can also alter local and regional climate (Boucher et al. 2004).

Rosenzweig et al. (2004) pointed out that while changes in the hydrological systems will influence the demand for and supply of water for irrigation, in addition future socioeconomic pressures will increase the competition for water between irrigation needs and nonagricultural users due to population and economic growth. Global estimates show an increase in the number of people living in water-stressed regions despite the projected increase in global water availability, suggesting that regional precipitation patterns and demographic and socio-economic factors play an important role on future global water stress (Arnell 2004; Alcamo et al. 2007b).

Agriculture is by far the biggest global user of freshwater resources and consequently highly vulnerable to climate change. Globally, around 70 percent of all available freshwater is used for irrigation, 22 percent is used by industry and 8 percent is used for residential purposes (United Nations 2003). In most developing countries, the agricultural sector provides the main livelihood and employment for most of the population and contributes considerably to national GDP. Therefore, reductions in agricultural production caused by future climate change could seriously weaken food security and worsen the livelihood conditions for the rural poor (Commission for Africa 2005).

The World Bank (2007) identifies five main factors through which climate change will affect the productivity of agricultural crops: changes in precipitation, temperature, carbon dioxide $\left(\mathrm{CO}_{2}\right)$ fertilization, climate variability, and surface water runoff. Increased climate variability and droughts will affect livestock production as well. Crop production is directly influenced by precipitation and temperature. Precipitation determines the availability of freshwater and the level of soil moisture, which are critical inputs for crop growth. Based on an econometric analysis, Reilly et al. (2003) found that higher precipitation leads to a reduction in yield variability. Therefore, higher precipitation will reduce the yield gap between rainfed and irrigated agriculture, but it may also have a negative impact if extreme precipitation causes flooding (Falloon and Betts 2009).

Temperature and soil moisture determine the length of growing season and control the crop's development and water requirements. In general, higher temperatures will shorten the freeze periods, promoting cultivation in cool-climate marginal croplands. However, in arid and semi arid areas, higher temperatures will shorten the crop cycle and reduce crop yields (IPCC 2007). A higher atmospheric concentration of carbon dioxide enhances plant growth 
and increases water use efficiency $\left(\mathrm{CO}_{2}\right.$ fertilization) and so affects water availability (e.g. Betts et al. 2007; Gedney et al. 2006; Long et al. 2006).

Climate variability, especially changes in rainfall patterns, is particularly important for rainfed agriculture. Soil moisture limitations reduce crop productivity and increase the risk of rainfed farming systems. Although the risk of climate variability is reduced by the use of irrigation, irrigated farming systems are dependent on reliable water resources, therefore they may be exposed to changes in the spatial and temporal distribution of river flow (CA 2007).

The aim of our paper is to assess how climate change impacts on water availability influence agricultural production world-wide. As climate variables we use predicted changes in global precipitation, temperature and river flow under the IPCC SRES A1B and A2 scenarios from Falloon and Betts (2006) and Johns et al. (2006) and include the effect of $\mathrm{CO}_{2}$ fertilization as well. All these variables play an important role in determining agricultural outcomes. Temperature and $\mathrm{CO}_{2}$ fertilization affect both rainfed and irrigated crop production. While precipitation is directly related to runoff and soil moisture and hence to rainfed production; river flow is directly related to irrigation water availability and hence to irrigated production. The analysis is carried out using the new version of the GTAP-W model. Unlike earlier studies we are able to take into account changes in river flow since GTAP-W distinguishes between rainfed and irrigated agriculture and implements water as an explicit factor of production for irrigated agriculture. The GTAP-W model (Calzadilla et al. 2008a) is a global computable general equilibrium (CGE) model that allows for a rich set of economic feedbacks and for a complete assessment of the welfare implications of alternative development pathways. Therefore, our methodology allows us to study the impacts of future availability of water resources on agriculture and within the context of international trade taking into account a more complete set of climate change impacts (see section 2 for more details on the literature).

The remainder of the paper is organized as follows: the next section briefly reviews the literature on economic models of water use including studies of climate change impacts. Section 3 describes the revised version of the GTAP-W model. Section 4 focuses on the future baseline simulations. Section 5 describes the data used and lays down the simulation scenarios. Section 6 discusses the principal results and section 7 concludes. 


\section{Economic models of water use}

Economic models of water use have generally been applied to look at the direct effects of water policies, such as water pricing or quantity regulations, on the allocation of water resources. Partial and general equilibrium models have been used. While partial equilibrium analysis focus on the sector affected by a policy measure assuming that the rest of the economy is not affected, general equilibrium models consider other sectors or regions as well to determine the economy-wide effect; partial equilibrium models tend to have more detail. Most of the studies using either of the two approaches analyze pricing of irrigation water only (for an overview of this literature see Johansson et al. 2002). Rosegrant et al. (2002) used the IMPACT model to estimate demand and supply of food and water to 2025. While the IMPACT model covers a wide range of agricultural products and regions, other sectors are excluded; it is a partial equilibrium model.

Studies of water use using general equilibrium approaches are generally based on data for a single country or region assuming no effects for the rest of the world of the implemented policy (for an overview of this literature see Calzadilla et al. 2008a or Dudu and Chumi 2008). All of these CGE studies have a limited geographical scope. Berittella et al. (2007) and Calzadilla et al. (2008a) are an exception. Calzadilla et al. (2008a) used the global CGE model GTAP-W, which accounts for water resources use in the agricultural sector, to analyze the economy-wide impacts of enhanced irrigation efficiency. They found that regional and global water savings are achieved when irrigation efficiency improves. Not only regions where irrigation efficiency changes are able to save water, but also other regions are induced to conserve water. They show mostly positive welfare gains for water-stressed regions; for non-water scarce regions welfare gains are more mixed and mostly negative. Calzadilla et al. (2010) used the same model to investigate the role of green (rainfall) and blue (irrigation) water resources in agriculture. They evaluated different scenarios of sustainable water use in the agricultural sector and found a clear trade-off between economic welfare and environmental sustainability. In a combined analysis using the IMPACT and GTAP-W models, Calzadilla et al. (2009) evaluated the efficacy of two adaptation measures to cope with climate change in Sub-Saharan Africa. They found that an increase in agricultural productivity achieves better outcomes than an expansion of irrigated areas, due to the low initial irrigated areas in the region.

Using a previous version of the GTAP-W model, Berrittella et al. (2006, 2007, 2008a and 2008b) analyzed the economic impact of various water resource policies. Unlike the predecessor GTAP-W, the revised GTAP-W model, used here, distinguishes between rainfed 
and irrigated agriculture. The new production structure of the model introduces water as an explicit factor of production and accounts for substitution possibilities between water and other primary factors.

Despite the global scale of climate change and the fact that food products are traded internationally, climate change impacts on agriculture have mostly been studied at the farm (e.g. Abler et al. 1998), the country or the regional level (e.g. Darwin et al. 1995; Verburg et al. 2008; Calzadilla et al 2009). Early studies of climate change impacts on global agriculture analyzed the economic effects of doubling the atmospheric carbon dioxide concentration based on alternative crop response scenarios with and without $\mathrm{CO}_{2}$ effects on plant growth. Results indicate that the inclusion of $\mathrm{CO}_{2}$ fertilization is likely to offset some of the potential welfare losses generated by climate change (Kane et al. 1992; Reilly et al. 1994; Rosenzweig and Parry 1994; Tsigas et al. 1997; Darwin and Kennedy 2000).

While theses approaches were unable to analyze adaptation options at farm or regional level, global CGE models that capture regional changes in agricultural inputs and managements options avoid these limitations. Darwin et al. (1995) used the Future Agricultural Resources Model (FARM) to study the role of adaptation in adjusting to new climate conditions. The FARM model differentiates six land classes according to the length of the growing season and is composed of a global CGE model and a geographic information system that links climate with production possibilities at regional-level. The results suggest that farm-level adaptations might mitigate any negative impacts induced by climate change. In a more recent analysis, Darwin (2004) suggested that regions with a relatively large share of income from agricultural exports may be vulnerable not only to direct climate-induced agricultural damages, but also to positive impacts induced by greenhouse gas emissions elsewhere.

Based on the general equilibrium Basic Linked System (BLS) model, Fischer et al. (1994, 1996) studied the potential biophysical responses of major food crops to a doubling of $\mathrm{CO}_{2}$ concentrations as well as the socio-economic consequences for the period 1990-2060. Parry et al. (1999) used the same model to look at the world's food security, estimating that climate change may increase the number of people at risk of hunger by around 80 million people in 2080. The BLS model has been used in conjunction with the Agro-Ecological Zone (AEZ) model to analyze potential impacts of climate change in agro-ecological and socioeconomic systems up to 2080 (Fischer et al. 2005; Fischer et al. 2007; Tubiello and Fischer 2007). The results suggest regional and temporal asymmetries in terms of impacts due to diverse climate and socio-economic structures. Adaptations on-farm and via market 
mechanisms are going to be important contributors to limiting the severity of impacts. Mitigation efforts could potentially reduce the global cost of climate change and decline the number of additional people at risk of malnutrition.

None of these studies have water as an explicit factor of production, as does our GTAP-W model. Moreover, most of these studies are based on scenarios related to a doubling of $\mathrm{CO}_{2}$ concentration, not taking into account the timing of the expected change in climate. Despite the considerable uncertainty in future climate projections (IPCC 2007), detailed information on the impacts of changes in precipitation, temperature and $\mathrm{CO}_{2}$ fertilization on crop yields is available, as well as the benefits of adaptation strategies. However, there is a lack of information about potential impacts of changes in river flow on irrigated agriculture. Our approach, based on the global CGE model GTAP-W, allows us to distinguish between rainfed and irrigated agriculture as well as to analyze how economic actors in one region/sector might respond to climate-induced economic changes in another region/sector. We analyze climate change impacts on global and regional agriculture at two time periods (2020s and 2050s). We use projected changes in global precipitation, temperature and river flow under the IPCC SRES A1B and A2 scenarios; as well as $\mathrm{CO}_{2}$ fertilization effects on crop growth.

\section{The GTAP-W model}

In order to assess the systemic general equilibrium effects of climate change impacts on global agriculture, we use a multi-region world CGE model, called GTAP-W. The model is a further refinement of the GTAP model ${ }^{2}$ (Hertel 1997), and is based on the version modified by Burniaux and Truong ${ }^{3}$ (2002) as well as on the previous GTAP-W model introduced by Berrittella et al. (2007).

\footnotetext{
2 The GTAP model is a standard static CGE model distributed with the GTAP database of the world economy (www.gtap.org). For detailed information see Hertel (1997) and the technical references and papers available on the GTAP website.

${ }^{3}$ Burniaux and Truong (2002) developed a special variant of the model, called GTAP-E. The model is best suited for the analysis of energy markets and environmental policies. There are two main changes in the basic structure. First, energy factors are separated from the set of intermediate inputs and inserted in a nested level of substitution with capital. This allows for more substitution possibilities. Second, database and model are extended to account for $\mathrm{CO}_{2}$ emissions related to energy consumption.
} 
The new GTAP-W model is based on the GTAP version 6 database, which represents the global economy in 2001, and on the IMPACT 2000 baseline data. The model has 16 regions and 22 sectors, 7 of which are in agriculture. ${ }^{4}$ The most significant change and principal characteristic of version 2 of the GTAP-W model is the new production structure, in which the original land endowment in the value-added nest has been split into pasture land (grazing land used by livestock) and land for rainfed and for irrigated agriculture. The last two types of land differ as rainfall is free but irrigation development is costly. As a result, land equipped for irrigation is generally more valuable as yields per hectare are higher. To account for this difference, we split irrigated agriculture further into the value for land and the value for irrigation. The value of irrigation includes the equipment but also the water necessary for agricultural production. In the short-run the cost of irrigation equipment is fixed, and yields in irrigated agriculture depend mainly on water availability. The tree diagram in Figure A1 in Annex A represents the new production structure.

Land as a factor of production in national accounts represents "the ground, including the soil covering and any associated surface waters, over which ownership rights are enforced” (United Nations 1993). To accomplish this, we split for each region and each crop the value of land included in the GTAP social accounting matrix into the value of rainfed land and the value of irrigated land using its proportionate contribution to total production. The value of pasture land is derived from the value of land in the livestock breeding sector.

In the next step, we split the value of irrigated land into the value of land and the value of irrigation using the ratio of irrigated yield to rainfed yield. These ratios are based on IMPACT data. The numbers indicate how relatively more valuable irrigated agriculture is compared to rainfed agriculture for particular land parcels. The magnitude of additional yield differs not only with respect to the region but also to the crop. On average, producing rice using irrigation is relatively more productive than using irrigation for growing oil seeds, for example. Regionally, on average more crops are grown under irrigation in South America compared to North Africa or Sub-Saharan Africa.

The procedure we described above to introduce the four new endowments (pasture land, rainfed land, irrigated land and irrigation) allows us to avoid problems related to model calibration. In fact, since the original database is only split and not altered, the original regions' social accounting matrices are balanced and can be used by the GTAP-W model to

\footnotetext{
${ }^{4}$ See Table A1 in Annex A for the regional, sectoral and factoral aggregation used in GTAP-W.
} 
assign values to the share parameters of the mathematical equations. For detailed information about the social accounting matrix representation of the GTAP database see McDonald et al. (2005).

As in all CGE models, the GTAP-W model makes use of the Walrasian perfect competition paradigm to simulate adjustment processes. Industries are modelled through a representative firm, which maximizes profits in perfectly competitive markets. The production functions are specified via a series of nested constant elasticity of substitution functions (CES) (Figure A1). Domestic and foreign inputs are not perfect substitutes, according to the so-called “Armington assumption”, which accounts for product heterogeneity. ${ }^{5}$

A representative consumer in each region receives income, defined as the service value of national primary factors (natural resources, pasture land, rainfed land, irrigated land, irrigation, labour and capital). Capital and labour are perfectly mobile domestically, but immobile internationally. Pasture land, rainfed land, irrigated land, irrigation and natural resources are imperfectly mobile. While perfectly mobile factors earn the same market return regardless of where they are employed, market returns for imperfectly mobile factors may differ across sectors. The national income is allocated between aggregate household consumption, public consumption and savings. The expenditure shares are generally fixed, which amounts to saying that the top level utility function has a Cobb-Douglas specification. Private consumption is split in a series of alternative composite Armington aggregates. The functional specification used at this level is the constant difference in elasticities (CDE) form: a non-homothetic function, which is used to account for possible differences in income elasticities for the various consumption goods. ${ }^{6}$ A money metric measure of economic welfare, the equivalent variation, can be computed from the model output. ${ }^{7}$

In the original GTAP-E model, land is combined with natural resources, labour and the capital-energy composite in a value-added nest. In our modelling framework, we

\footnotetext{
${ }^{5}$ The Armington assumption of nationally differentiated products is commonly adopted in global trade models to explain cross-hauling of similar products (when a country appears to import and export the same good in the same period) and to track bilateral trade flows.

${ }^{6}$ A non-homothetic utility function implies that with different income levels a households budget shares spent on various commodities changes.

${ }^{7}$ The equivalent variation measures the welfare impact of a policy change in monetary terms. It is defined as the change in regional household income at constant prices that is equivalent to the proposed change.
} 
incorporate the possibility of substitution between land and irrigation in irrigated agricultural production by using a nested constant elasticity of substitution function (Figure A1). The procedure how the elasticity of factor substitution between land and irrigation ( $\left.\sigma_{\mathrm{LW}}\right)$ was obtained is explained in more detail in Calzadilla et al. (2008a). Next, the irrigated land-water composite is combined with pasture land, rainfed land, natural resources, labour and the capital-energy composite in a value-added nest through a CES structure.

The IMPACT model provides detailed information on green water use in rainfed production (defined as effective rainfall); and both green and blue water use in irrigated production (blue water or irrigation is defined as the water diverted from water systems). ${ }^{8}$ In the GTAP-W benchmark equilibrium, water used for irrigation is supposed to be identical to the volume of blue water used for irrigated agriculture in the IMPACT model. An initial sector and region specific shadow price for irrigation water can be obtained by combining the social accounting matrix information about payments to factors and the volume of water used in irrigation from IMPACT. Contrary to blue water, green water used in rainfed and irrigated crop production has no price. It is modelled exogenously in the GTAP-W model using information from IMPACT.

The distinction between rainfed and irrigated agriculture within the production structure of the GTAP-W model allows us to study expected physical constraints on water supply due to, for example, climate change. In fact, changes in rainfall patterns can be exogenously modelled in GTAP-W by changes in the productivity of rainfed and irrigated land. In the same way, water excess or shortages in irrigated agriculture can be modelled by exogenous changes to the initial irrigation water endowment.

\section{Future baseline simulations}

Future climate change impacts on agriculture are analyzed at two time periods: the 2020s and 2050s. Economy-wide climate change impacts are compared to alternative no climate change benchmarks for each period. To obtain a future benchmark equilibrium dataset for the GTAP-

\footnotetext{
${ }^{8}$ Green water used in crop production or effective rainfall is part of the rainfall that is stored in the root zone and can be used by the plants. The effective rainfall depends on the climate, the soil texture, the soil structure and the depth of the root zone. The blue water used in crop production or irrigation is the applied irrigation water diverted from water systems. The blue water used in irrigated areas contributes additionally to the freshwater provided by rainfall (Rosegrant et al. 2002).
} 
W model we use the methodology described by Dixon and Rimmer (2002). This methodology allows us to find a hypothetical general equilibrium state in the future imposing projected values for some key economic variables in the initial calibration dataset. In this way, we impose projected changes in regional endowments (labour, capital, natural resources, rainfed land, irrigated land and irrigation), in regional factor-specific and multifactor productivity and in regional population. We use estimates of regional labour productivity, labour stock and capital stock from the G-Cubed model (McKibbin and Wilcoxen 1998). Changes in the allocation of rainfed and irrigated land within a region as well as irrigation and agricultural land productivity are implemented according to estimates from the IMPACT model (Rosegrant et al. 2002). Finally, we use the medium-variant population estimates from the Population Division of the United Nations (United Nations 2004).

The detailed information supplied by the IMPACT model (demand and supply of water, demand and supply of food, rainfed and irrigated production and rainfed and irrigated area) to the GTAP-W model allows for a calibration of the baseline year and future benchmark equilibriums. We use the IMPACT 2050 simulation without climate change to find a hypothetical general equilibrium in 2020 and 2050. The 2020 data is obtained by linear interpolation between the 2000 baseline data and the 2050 simulation without climate change.

Compared to the 2000 baseline data (Table B1 in Annex B), the IMPACT model projects a growth in both harvested area and crop productivity for 2020 under normal climate conditions (Table B2 in Annex B). The world's harvested area is expected to increase by about 1.1 percent between 2000 and 2020. This is equivalent to a total area of 1.3 billion hectares in 2020, 34.2 percent of which is under irrigation. For the same period, the world's crop production is expected to increase by 32.8 percent. Rainfed crop production increases by 31.3 percent, despite a decrease in rainfed area by 0.1 percent. Irrigated crop production and harvested area increase by 34.8 and 3.5 percent, respectively.

A similar tendency is observed in 2050 (Table B3 in Annex B). Between 2000 and 2050, the world's crop production is expected to increase by 91.7 percent. Rainfed and irrigated production increase by 88.0 and 96.8 percent, respectively. For the same period, the world's crop area is expected to increase by 2.8 percent. While rainfed crop area decreases by 0.2 percent, irrigated crop area increases by 8.7 percent. In 2050, farmers in Sub-Saharan Africa, South Asia and China are expected to use around half of the world's crop area, accounting for 37.8 percent of the world's crop production. Sub-Saharan Africa and South Asia are expected to use around 38.3 percent of the world's rainfed area and produce around 
22.1 percent of the world's rainfed production. Similarly, South Asia and China are expected to use around 56.4 percent of the world's irrigated area and produce around 41.8 percent of the world's irrigated production.

\section{Data input and design of simulation scenarios}

We analyze climate change impacts on global agriculture based on predicted changes in the magnitude and distribution of global precipitation, temperature and river flow from Falloon and Betts (2006) and Stott et al. (2006). They analyzed data from simulations using the Hadley Centre Global Environmental Model including a dynamic river routing model (HadGEM1-TRIP) (Johns et al. 2006; Martin et al. 2006) over the next century and under the IPCC SRES A1B and A2 scenarios. Their results are in agreement with previous studies (e.g. Arnell 2003; Milly et al. 2005). For consistency, we note here that while these HadGEM1 simulations did include the impact of elevated $\mathrm{CO}_{2}$ concentrations on runoff, they did not include explicit representations of crops, irrigation, groundwater or dams.

A relatively optimistic scenario (A1B) is contrasted with a relatively pessimistic scenario (A2), covering in this way part of the uncertainty of future climate change impacts on water availability. As described in the SRES report (IPCC 2000), the A1B group of the A1 storyline and scenario family considers a balance between fossil intensive and non-fossil energy sources. It shows a future world of very rapid economic growth, global population that peaks in mid-century and decline thereafter, as well as rapid and more efficient technology development. It considers convergence among regions, with a substantial reduction in regional differences in per capita income. The SRES A2 scenario describes a very heterogeneous world. It considers self-reliance and preservation of local identities, and continuously increasing global population. Economic development is primarily regionally oriented and per capita economic growth and technological change are more fragmented and slower than in other storylines.

The analysis is carried out at two time periods: the 2020s (medium-term) and 2050s (long-term). Both time periods represent the average for the 30-year period centred on the given year; the 2020s represents the average for the 2006-2035 period and the 2050s represents the average for the 2036-2065 period. Predicted changes in precipitation, temperature and river flow under the two emission scenarios are compared to a historicanthropogenic baseline simulation, which represents the natural variability of these variables. It is the 30-year average for the 1961-1990 period. We use annual average precipitation, 
temperature and river flow data. Therefore, in the current study we do not consider local scale impacts nor changes in seasonality or extremes.

\section{River Flow}

Compared to the average for the 1961-1990 period (historic-anthropogenic simulation), Falloon and Betts (2006) found large inter-annual and decadal variability of the average global total river flow, with an initial decrease until around 2060. For the 2071-2100 period, the average global total river flow is projected to increase under both SRES scenarios (around 4 percent under the A1B scenario and 8 percent under the A2 scenario). The A2 scenario produced more severe and widespread changes in river flow than the A1B scenario.

Figure 1 shows for the two time periods (2020s and 2050s) and for the two emission scenarios (A1B and B2) a global map of predicted changes in river flow relative to the 19611990 period. Large regional differences are observed. For both emission scenarios and time periods, the number of countries subject to decreasing river flow is projected to be higher than those with increasing river flow. In general, similar regional patterns of changes in river flow are observed under the two emission scenarios and time periods. Significant decreases in river flow are predicted for northern South America, southern Europe, the Middle East, North Africa and southern Africa. In contrast, substantial increases in river flow are predicted for boreal regions of North America and Eurasia, western Africa and southern Asia. Some exceptions are parts of eastern Africa and the Middle East, where changes in river flow vary depending on the scenario and time period. Additionally under the A1B-2050s scenario, river flow changes are positive for China and negative for Australia and Canada, while opposite trends were observed for other scenarios and time periods.

Figure 1 about here

River flow is a useful indicator of freshwater availability for agricultural production. Irrigated agriculture relies on the availability of irrigation water from surface and groundwater sources, which depend on the seasonality and interannual variability of river flow. Therefore, river flow limits a region's water supply and hence constrains its ability to irrigate crops. Table 1 shows for the two time periods and emission scenarios regional changes in river flow and water supply according to the 16 regions defined in Table A1 (Annex A). Regional changes in river flow are related to regional changes in water supply by the runoff elasticities of water supply estimated by Darwin et al. (1995) (Table 1). The runoff elasticity of water supply is defined as the proportional change in a region's water supply divided by the proportional change in a region's runoff. That is, an elasticity of 0.5 indicates 
that a 2 percent change in runoff results in a 1 percent change in water supply. Regional differences in elasticities are related to differences in hydropower capacity, because hydropower production depends on dams, which enable a region to store water that could be withdrawn for irrigation or other uses during dry and rainy seasons.

Table 1 about here

\section{Precipitation}

Falloon and Betts (2006) pointed out that predicted changes in river flow were largely driven by changes in precipitation, since the pattern of changes in precipitation were very similar to the pattern of changes in river flow, and the changes in evaporation opposed the changes in river flow in some regions. Figure 2 shows for the two time periods and for the two emission scenarios a global map of predicted changes in precipitation relative to the 1961-1990 period. Decreases in both river flow and precipitation were predicted for northern South America and southern Europe while evaporation was reduced - hence the reduction in river flow was driven mostly by the reduction in rainfall. In high latitude rivers, increases in river flow and rainfall were predicted along with increases in evaporation, so the river flow changes here were mostly driven by changes in rainfall. In tropical Africa, increases in river flow and rainfall were predicted along with decreases in evaporation, so changes in rainfall and evaporation both contributed to the river flow changes.

Figure 2 about here

The exposure of irrigated agriculture to the risk of changes in climate conditions is more limited compared to rainfed agriculture which depends solely on adequate soil moisture. Therefore, rainfed production is highly vulnerable to changes in precipitation. Regional crop yield responses to changes in precipitation and temperature are based on Rosenzweig and Iglesias (1994) (Table B4 in Annex B). They used the International Benchmark Sites Network for Agrotechnology Transfer (IBSNAT) dynamic crop growth models to estimate climate change impacts on crop yields at 112 sites in 18 countries, representing both major production areas and vulnerable regions at low, mid and high latitudes. The IBSNAT models have been validated over a wide range of environments and are not specific to any particular location or soil type. Rosenzweig and Iglesias (1994) used the IBSNAT crop models CERES (wheat, maize, rice and barley) and SOYGRO (soybeans) to analyze crop yield responses to arbitrary incremental changes in precipitation $(+/-20 \%)$ and temperature $\left(+2^{\circ} \mathrm{C}\right.$ and $\left.+4^{\circ} \mathrm{C}\right)$. 


\section{Temperature}

The regional patterns of temperature increases were similar for the two emission scenarios and time periods (Figure 3). Larger temperature increases are expected at high latitudes and under the SRES A1B scenario.

\section{Figure 3 about here}

Crop production is directly influenced by precipitation and temperature. Temperature and soil moisture determine the length of growing season and control the crop's development and water requirements. Crop yield responses to higher temperature levels are based on Rosenzweig and Iglesias (1994) (Table B4 in Annex B).

\section{$\mathrm{CO}_{2}$ Fertilization}

Our estimates of the $\mathrm{CO}_{2}$ fertilization effect on crop yields are based on information presented by Tubiello et al. (2007). They reported yield response ratios for C3 and C4 crops to elevated $\mathrm{CO}_{2}$ concentrations in the three major crop models (CERES, EPIC and AEZ). The yield response ratio of a specific crop is the yield of that crop at elevated $\mathrm{CO}_{2}$ concentration, compared by the yield at a reference scenario. In our analysis, we use the average crop yield response of the three crop models. The $\mathrm{CO}_{2}$ concentrations levels in 2020 and 2050 are consistent with the IPCC SRES A1B and A2 scenarios. Thus, for 2020 and under the SRES A1B scenario crop yield is expected to increase by 5.5 and 2.4 percent at $418 \mathrm{ppm}$ for C3 and C4 crops, respectively. For the same period, crop yield increases under the SRES A2 scenario are expected to be slightly lower, 5.2 and 2.3 percent at 414 ppm for C3 and C4 crops, respectively. $\mathrm{CO}_{2}$ concentration levels in 2050 are expected to be similar for both SRES scenarios (522 ppm), increasing C3 crop yields by 12.6 percent and C4 crop yields by 5.2 percent.

\section{Simulation Scenarios}

Based on the regional changes in river flow (water supply), precipitation and temperature presented in Table 1, we evaluate the impact of climate change on global agriculture according to six scenarios. Each scenario is implemented for the two time periods and emission scenarios presented above. Table 2 presents the main characteristics of the six simulation scenarios.

\section{Table 2 about here}

The first three scenarios are directly comparable to previous studies. They show the impacts of changes in precipitation, temperature and $\mathrm{CO}_{2}$ fertilization on crop yields. These 
scenarios are implemented in such a way that no distinction is made between rainfed and irrigated agriculture, as was common in previous work. The precipitation-only scenario analyzes changes in precipitation, the precipitation- $\mathrm{CO}_{2}$ scenario analyzes changes in precipitation and $\mathrm{CO}_{2}$ fertilization, and the precipitation-temperature- $\mathrm{CO}_{2}$ scenario analyzes changes in precipitation, temperature and $\mathrm{CO}_{2}$ fertilization.

The last three scenarios distinguish between rainfed and irrigated agriculture -the main feature of the new version of the GTAP-W model. Thus, the water-only scenario considers that climate change may bring new problems to irrigated agriculture related to changes in the availability of water for irrigation. Reductions in river flow diminish water supplies for irrigation increasing the climate risk for irrigated agriculture. In addition, climate change is expected to affect rainfed agriculture by changing the level of soil moisture through changes in precipitation. In this scenario, changes in precipitation modify rainfed crop yields, while changes in water supply modify the irrigation water endowment for irrigated crops.

Future climate change would modify regional water endowments and soil moisture, and in response the distribution of harvested land would change. Therefore, the water-land scenario explores possible shifts in the geographical distribution of irrigated agriculture. It assumes that irrigated areas could expand in regions with higher water supply. Similarly, irrigated farming can become unsustainable in regions subject to water shortages. In this scenario, in addition to changes in precipitation and water supply, irrigated areas in GTAP-W are adjusted according to the changes in regional water supply presented in Table 1 . That is, the relative change in the supply of irrigated land equals the relative change in water supply.

The last scenario, called all-factors, shows the impacts of all climate variables affecting agricultural production. Temperature and $\mathrm{CO}_{2}$ fertilization affect both rainfed and irrigated crop yields, precipitation affects rainfed crop yields and water supply influences both the irrigation water endowment and the distribution of irrigated crop areas.

\section{Results}

Climate change impacts agricultural productivity, modifying agricultural production worldwide. Table 3 shows for the two time periods (2020s and 2050s) and SRES scenarios (A1B and A2) the percentage changes in total crop production by region and simulation scenario. Let us first consider the three simulation scenarios that do not distinguish between rainfed and irrigated agriculture. For both time periods, changes in precipitation-only slightly increase world food production under the SRES A1B scenario and decrease under the SRES A2 scenario. As expected, the addition of $\mathrm{CO}_{2}$ fertilization in the analysis causes an increase 
in world food production. However, the $\mathrm{CO}_{2}$ fertilization effect is not strong enough to compensate world food losses caused by higher temperatures (compare precipitation- $\mathrm{CO}_{2}$ and precipitation-temperature- $\mathrm{CO}_{2}$ scenarios). For the 2050s and under the precipitationtemperature- $\mathrm{CO}_{2}$ scenario, world food production is expected to decrease by around 2.5 percent under both emission scenarios. Our results are thus comparable to Parry et al. (1999), probably because we used roughly the same input data. Other studies foresee an increase in the world food production due to climate change.

\section{Table 3 about here}

At the regional level, climate change impacts on food production vary widely. Under the precipitation-temperature- $\mathrm{CO}_{2}$ scenario, food production decreases particularly in developing regions, with the exception of China and Sub-Saharan Africa, where production increases as other regions lose their comparative advantages. An opposite trend is observed in developed regions, where food production is expected to increase. Exceptions are the former Soviet Union, the United States and Canada, regions with high yield responses to temperature increases.

Patterns in global and regional water use generally follow those observed in agricultural production. Table 4 shows the effect of the different scenarios on total agricultural water use. Under the precipitation-temperature- $\mathrm{CO}_{2}$ scenario, reductions in global water use are more pronounced for the 2050s and under the SRES A1B scenario. For the 2050s, global water use decreases by 2.8 and 2.4 percent for the SRES A1B and A2 scenario, respectively. For the same simulation scenario and time period, reductions in regional water use are more pronounced in water-scare regions such as North Africa and the Middle East. Water use in these regions decreases by between 24 to 50 percent, depending on the SRES scenario. Increases in agricultural water use are higher in China and Australia and New Zealand, between 9 to 13 percent depending on the SRES scenario.

\section{Table 4 about here}

Table 5 shows changes in welfare by region, time period and scenario. At the global level, changes in welfare are more pronounced in the 2050s. Although $\mathrm{CO}_{2}$ fertilization improves agricultural production and generates welfare gains (precipitation- $\mathrm{CO}_{2}$ scenario), they are not strong enough to offset the negative effects of changes in precipitation and higher temperature (precipitation-temperature- $\mathrm{CO}_{2}$ scenario). At the regional level, changes in welfare vary across regions and SRES scenarios. Under the precipitation-temperature-CO scenario, welfare gains are expected in most of the developed regions and welfares losses affect most of the developing regions. 


\section{Table 5 about here}

Above, we mimic previous studies. Below we take advantage of the distinction between rainfed and irrigated agriculture in GTAP-W. As the risk of climate change is lower for irrigated agriculture, the initial decrease in global irrigated crop production under the precipitation-only scenario turns into an increase under the water-only scenario (Table 6). That is, changes in precipitation do not have a direct effect on irrigated crop production but changes in river flow do (water-only scenario). Therefore, irrigated crop production is less vulnerable to changes in water resources due to climate change.

\section{Table 6 about here}

While global irrigated production decreases and rainfed production increases under the precipitation-only scenario, an opposite trend is observed under the water-only scenario (except for the SRES A2 scenario in the 2020s). However, changes in total world crop production under both scenarios are similar (Table 6). This implies that whenever irrigation is possible (water-only scenario) food production relies on irrigated crops. As a result, global water use increases or decreases less and global welfare losses are less pronounced or even positive (Table 6). For the 2050s, global welfare losses are about half those under the precipitation-only scenario. At the regional level, differences in the results are marked for water-scarce regions such as North Africa and the Middle East, where irrigation plays an important role in crop production.

The distinction between rainfed and irrigated agriculture in GTAP-W allows us to separate green (rainfall) and blue (irrigation) water used in crop production. While changes in irrigated production modify the use of blue water resources, changes in rainfed and irrigated production modify the use of green water resources. Comparing the precipitation-only and the water-only scenario, blue water use follows the same pattern as irrigated crop production (Table 6). It decreases under the precipitation-only scenario and increases under the wateronly scenario.

When irrigated crop areas are affected by changes in irrigation water supply (waterland scenario), global irrigated crop production decreases slightly for the 2020s and increases for the 2050s (compared to the water-only scenario). The same trend is observed for global crop production and welfare. Following changes in regional water supply, the world's irrigated crop areas expand under both time periods and emission scenarios, except for the SRES A2 scenario in the 2020s (water-land scenario) (Table 6). For the 2020s, world irrigated areas are expected to increases by around 0.5 million hectares under the SRES A1B scenario and decrease by around 4 million hectares under the SRES A2 scenario. For the 
2050s, world irrigated areas increase by about 10 and 4 million hectares under the SRES A1B and A2 scenarios, respectively. At regional level (results not shown), irrigated areas expand mainly in the United States (SRES A1B - 2020s), China (SRES A1B - 2050s) and South Asia (SRES A1B and A2 - 2050s). Irrigated crop areas decline mainly in China and the Middle East under the SRES A2 scenario in the 2020s.

Impacts of changes in precipitation, temperature, $\mathrm{CO}_{2}$ fertilization, river flow and irrigation area on world agriculture are analyzed in the all-factors scenario. At the global level, total production decreases by around 0.5 percent in the 2020s and by around 2.3 in the 2050s. The decline is slightly more pronounced under the SRES A2 scenario (Table 3). At the regional level, total crop production increases in developed regions, with the exception of the former Soviet Union, the United States and Canada. Total crop production decreases in most of the developing regions, particularly in the Middle East, Southeast Asia and North Africa.

Changes in water supply for rainfed and irrigated agriculture lead to shifts in rainfed and irrigated production. Despite the increase in irrigated crop areas, global irrigated production declines between 3 to 6 percent, depending on the SRES scenario and time period. Expected declines are marked for the SRES A2 scenario and for the 2050s (Table 6, allfactors scenario). Irrigated crop production declines mainly in the United States, the Middle East, North Africa and South Asia (results not shown). These are regions with high negative yield responses to changes in temperature and where irrigated production contributes substantially to total crop production.

Changes in irrigated production drive changes in water use under the all-factors scenario. Blue, green and total water use decline with irrigated production. Under the SRES A2 scenario, climate change leads to a reduction in total water use world-wide by around 1.3 percent in the 2020s (82 cubic kilometres) and around 2.3 percent in the 2050s (187 cubic kilometres). Declines are less pronounced under the SRES A1 scenario (Table 4). At regional level, total water use declines largely in the Middle East, the former Soviet Union, Southeast Asia and the United States. Total water use reductions in these regions most than double in the 2050s.

Climate change modifies agricultural productivity affecting crop production and hence food prices. Figure 4 shows the percentage changes in sectoral crop production and world market prices for the all-factors scenario compared to the baseline simulations. Sectoral crop production decreases and market prices increase under both emission scenarios and time periods. With the exception of vegetables, fruits and nuts, larger declines in sectoral 
production and hence higher food prices are expected under the SRES A2 scenario in the 2020s. Changes in sectoral production and food prices are more pronounced in the 2050s and vary according to the crop type and SRES scenario. Higher market prices are expected for cereal grains, sugar cane, sugar beet and wheat (between 39 to 43 percent depending on the SRES scenario).

\section{Figure 4 about here}

Changes in agricultural production and prices induce changes in welfare. For the allfactors scenario, global welfare losses in the 2050s (around 283 and 269 billion USD under the SRES A1B and A2 scenario, respectively) are more than 15 times larger than those expected in the 2020s. Global welfare losses are slightly larger under the SRES A2 scenario in the 2020s and under the SRES A1B scenario in the 2050s (Table 5). The largest loss in global GDP due to climate change is estimated under the SRES A1B scenario at 280 billion USD, equivalent to 0.29 percent of global GDP (Table 6).

Figure 5 shows changes in global welfare by scenario and individual input variable. Comparing the differences between water-land and all-factors on the one hand and precipitation-only and precipitation-temperature- $\mathrm{CO}_{2}$ on the other hand, we see that adding carbon dioxide fertilization and warming to the mix has a clear negative effect on welfare. Comparing the individual effects of the input variables on welfare, we find that there is a small positive effect of carbon dioxide fertilization and a large negative effect of warming. However, the negative effect of warming is much smaller if we distinguish between rainfed and irrigated agriculture (by considering changes in river flow) and let irrigated areas adjust to the new situation.

\section{Figure 5 about here}

At the regional level, welfare varies widely showing that regions are not only influenced by regional climate change, but also by climate-induced changes in competitiveness. Figure 6 shows, for the all-factors scenario, changes in welfare as a function of the regional changes in precipitation and the terms of trade. Each $(x, y)$ pair contains information for a specific region, time period and emission scenario. Temperature is the main climate variable explaining welfare changes. Figure 6(a) shows a negative relationship between welfare and temperature. Temperature alone is able to explain around 20 percent of the variation in regional welfare $\left(\mathrm{R}^{2}=0.21\right)$. However, this negative trend is mainly driven by large welfare losses and temperature increase in the former Soviet Union for the 2050's (right bottom of the figure). The adjusted trend line without those observations shows no relationship between welfare and temperature, suggesting that positive and negative welfare 
impacts are likely to be distributed unevenly. Climate change impacts agricultural productivity and hence modifies the comparative advantages of regional agricultural production. Figure 6(b) shows a clear positive relationship between changes in regional welfare and the terms of trade. Around 70 percent of the regional variations in welfare are explained by changes in the terms of trade $\left(R^{2}=0.71\right)$.

Figure 6 about here

Under the all-factors scenario, welfare declines mainly in regions with high yield responses to changes in temperature (the former Soviet Union, South Asia, the Middle East and Southeast Asia). Regional welfare gains are relatively low in magnitude compared to welfare losses. Regions like South America, Sub-Saharan Africa and China benefit through shifts in competitiveness and international trade. Although both developed and developing regions are expected to face welfare losses, climate change is expected to reduce welfare in a higher number of developing regions.

\section{Discussion and conclusions}

In this paper, we use a global computable general equilibrium model including water resources (GTAP-W) to assess climate change impacts on global agriculture. The distinction between rainfed and irrigated agriculture within the production structure of the GTAP-W model allows us to model green (rainfall) and blue (irrigation) water use in agricultural production. While previous studies do not differentiate rainfed and irrigated agriculture, this distinction is crucial, because rainfed and irrigated agriculture face different climate risk levels. Thus, in GTAP-W, changes in future water availability have different effects on rainfed and irrigated crops. While changes in precipitation are directly related to runoff and soil moisture and hence to rainfed production, changes in river flow are directly related to irrigation water availability and hence to irrigated production.

We use predicted changes in precipitation, temperature and river flow under the IPCC SRES A1B and A2 scenarios to simulate climate change impacts on global agriculture at two time periods: the 2020s and 2050s. We include in the analysis $\mathrm{CO}_{2}$ fertilization as well. Six scenarios are used, the first three scenarios analyzes agricultural impacts of changes in precipitation, temperature and $\mathrm{CO}_{2}$ fertilization without differentiating between rainfed and irrigated crops. The last three scenarios fully exploit the GTAP-W model and discriminate impacts in rainfed and irrigated systems.

The results show that when only projected changes in water availability are considered (precipitation-only and water-only scenario), total agricultural production in both 
time periods is expected to slightly increase under the SRES A1B scenario and decrease under the SRES A2 scenario. As expected, the inclusion of $\mathrm{CO}_{2}$ fertilization in the analysis causes an increase in world food production and generates welfare gains (precipitation- $\mathrm{CO}_{2}$ scenario). However, it is not strong enough to offset the negative effects of changes in precipitation and temperature (precipitation-temperature- $\mathrm{CO}_{2}$ scenario). For the 2050s and under the SRES A1B scenario, global agricultural production is expected to decrease by around 2.6 percent and welfare losses reach more than 327 billion USD. Results for the SRES A2 scenario are less pronounced.

Distinguishing between rainfed and irrigated agriculture, we find that irrigated production is less vulnerable to changes in water resources. When irrigation is possible, food production relies on irrigated crops, thus welfare losses are less pronounced. For the 2050s, global welfare losses account for less than half of the initially drop (compare precipitationonly and water-only scenario).

A joint analysis of the main climate variables affecting agricultural production (precipitation, temperature, river flow and $\mathrm{CO}_{2}$ fertilization) shows that global food production declines by around 0.5 percent in the 2020s and by around 2.3 in the 2050s. Declines under the SRES A2 scenario are slightly more pronounced (all-factors scenario). While crop production increases in many developed regions (exceptions are of the former Soviet Union, the United States and Canada), it decreases in most of the developing regions (mainly in the Middle East, Southeast Asia and North Africa).

Despite the increase in irrigated crop areas promoted by a higher irrigation water supply, global irrigated production declines between 3 to 6 percent, depending on the SRES scenario and time period. Irrigated crop production declines in regions with high negative yield responses to changes in temperature as well as regions where irrigated production contributes substantially to total crop production (the United States, the Middle East, North Africa and South Africa).

Global blue, green and total water use decline in the all-factors scenario. Climate change leads to a reduction in total water use world-wide by around 1.3 percent in the 2020s (82 cubic kilometres) and around 2.3 percent in the 2050s (187 cubic kilometres) (SRES A2 scenario). At regional level, total water use declines largely in the Middle East, the former Soviet Union, Southeast Asia and the United States.

Declines in food production rise food prices. Higher market prices are expected for all crops, mainly for cereal grains, sugar cane, sugar beet and wheat (between 39 to 43 percent depending on the SRES scenario). 
Changes in agricultural production and prices induce changes in welfare and GDP. Global welfare losses in the 2050s are expected to account for more than 265 billion USD, around 0.28 percent of global GDP (all-factors scenario). Independently of the SRES emission scenario and time period, the results show that regional welfare decreases with higher temperature levels and increases with improvements in the terms of trade. Thus, regions are not only affected by regional climate change, but also by climate-induced competitiveness changes.

Several limitations apply to the above results. First, in our analysis changes in precipitation, temperature and river flow are defined based on regional averages. We do not take into account differences between river basins within the same region. These local effects are averaged out. Second, we use annual average precipitation, temperature and river flow data, therefore we do not consider changes in the seasonality nor extreme events. Third, we have made no attempt to address uncertainty in our scenarios, other than by the use of two emission scenarios from only one climate model, which could generate biased estimates. Forth, in our analysis we do not consider any cost or investment associated to the expansion of irrigated areas. Therefore, our results might overestimate the benefits of some scenarios. These issues should be addressed in future research.

\section{Acknowledgements}

We had useful discussions about the topics of this article with Korbinian Freier, Jemma Gornall and Uwe Schneider. We would like to thank Nele Leiner and Daniel Hernandez for helping arranging the data set. This article is supported by the Federal Ministry for Economic Cooperation and Development, Germany under the project "Food and Water Security under Global Change: Developing Adaptive Capacity with a Focus on Rural Africa," which forms part of the CGIAR Challenge Program on Water and Food, by the Michael Otto Foundation

for Environmental Protection, and by the Joint DECC and Defra Integrated Climate Programme - DECC/Defra (GA01101). 


\section{References}

Abler, D., J. Shortle, A. Rose, R. Kamat, G. Oladosu. 1998. "Economic impacts of climate change in the Susquehanna River Basin.” In: Paper presented at American Association for the Advancement of Science Annual Meeting, Philadelphia.

Alcamo, J., N. Dronin, M. Endejan, G. Golubev, and A. Kirilenko. 2007a. “A new assessment of climate change impacts on food production shortfalls and water availability in Russia.” Global Environmental Change 17: 429-444.

Alcamo, J., M. Flörke, and M. Märker. 2007b. "Future long-term changes in global water resources driven by socio-economic and climatic changes.” Hydrological SciencesJournal-des Sciences Hydrologiques 52(2): 247-275.

Arnell, N.W. 2003. "Effects of IPCC SRES emissions scenarios on river runoff: a global perspective.” Hydrology and Earth System Sciences 7: 619-641.

Arnell, N.W. 2004. "Climate change and global water resources: SRES emissions and socioeconomic scenarios.” Global Environmental Change 14: 31-52.

Bates, B.C., Z.W. Kundzewicz, S. Wu, and J.P. Palutikof, eds. 2008. Climate Change and Water. Technical Paper of the Intergovernmental Panel on Climate Change, IPCC Secretariat, Geneva, $210 \mathrm{pp}$.

Barnett, T.P., J.C. Adam, and D.P. Lettenmaier. 2005. "Potential impacts of a warming climate on water availability in snow-dominated regions.” Nature 438, 303-309.

Berrittella, M., K. Rehdanz, and R.S.J. Tol. 2006. “The Economic Impact of the South-North Water Transfer Project in China: A Computable General Equilibrium Analysis.” Research unit Sustainability and Global Change FNU-117, Hamburg University and Centre for Marine and Atmospheric Science, Hamburg.

Berrittella, M., A.Y. Hoekstra, K. Rehdanz, R. Roson, and R.S.J. Tol. 2007. "The Economic Impact of Restricted Water Supply: A Computable General Equilibrium Analysis.” Water Research 41: 1799-1813.

Berrittella, M., K. Rehdanz, R. Roson, and R.S.J. Tol. 2008a. "The Economic Impact of Water Pricing: A Computable General Equilibrium Analysis.” Water Policy 10: 259-271.

Berrittella, M., K. Rehdanz, R.S.J. Tol, and Y. Zhang. 2008b. "The Impact of Trade Liberalisation on Water Use: A Computable General Equilibrium Analysis.” Journal of Economic Integration 23: 631-655.

Betts. R.A., O. Boucher, M. Collins, P.M. Cox, P.D. Falloon, N. Gedney, D.L. Hemming, C. Huntingford, C.D. Jones, D.M. Sexton, and M.J. Webb. "Projected increase in continental 
runoff due to plant responses to increasing carbon dioxide.” 2007. Nature 448(7157): 1037-41.

Boucher O., G. Myhre, and A. Myhre. 2004. "Direct human influence of irrigation on atmospheric water vapour and climate.” Clim Dyn 22: 597-603.

Boxall A.B.A., A. Hardy, S. Beulke, T. Boucard, L. Burgin, P.D. Falloon, P.M. Haygarth, T. Hutchinson, R.S. Kovats, G. Leonardi, L.S. Levy, G. Nichols, S.A. Parsons, L. Potts, D. Stone, E. Topp, D.B. Turley, K. Walsh, E.M.H. Wellington, and R.J. Williams. 2008. "Impacts of Climate Change on the Health Risks of Pathogens and Chemicals from Agriculture.” Environmental Health Perspectives 117: 508-514.

Burniaux, J.M. and T.P. Truong. 2002. “GTAP-E: An Energy Environmental Version of the GTAP Model.” GTAP Technical Paper no. 16.

CA. See Comprehensive Assessment of Water Management in Agriculture.

Calzadilla, A., K. Rehdanz, and R.S.J. Tol. 2008a. "Water scarcity and the impact of improved irrigation management: A CGE analysis.” Research unit Sustainability and Global Change FNU-160, Hamburg University and Centre for Marine and Atmospheric Science, Hamburg.

Calzadilla, A., K. Rehdanz, and R.S.J. Tol. 2010. "The Economic Impact of More Sustainable Water Use in Agriculture: A Computable General Equilibrium Analysis.” Journal of Hydrology 384: 292-305.

Calzadilla, A., T. Zhu, K. Rehdanz, R.S.J. Tol, and C. Ringler. 2009. "Economy-Wide Impacts of Climate Change on Agriculture in Sub-Saharan Africa.” Research unit Sustainability and Global Change FNU-170, Hamburg University and Centre for Marine and Atmospheric Science, Hamburg.

Commission for Africa. 2005. Our common interest: Report of the Commission for Africa. London: Commission for Africa.

Comprehensive Assessment of Water Management in Agriculture. 2007. Water for food, water for life: A comprehensive assessment of water management in agriculture. London and Colombo, Sri Lanka: Earthscan and International Water Management Institute.

Darwin, R. 2004. "Effects of greenhouse gas emissions on world agriculture, food consumption, and economic welfare.” Climatic Change 66: 191-238.

Darwin, R.F., and D. Kennedy. 2000. "Economic Effects of $\mathrm{CO}_{2}$ Fertilization of Crops: Transforming Changes in Yield into Changes in Supply.” Environ. Model. Assess. 5: 157-168. 
Darwin, R., M. Tsigas, J. Lewandrowski, and A. Raneses. 1995. "World Agriculture and Climate Change: Economic Adaptations.” Agricultural Economic Report 703, U.S. Department of Agriculture, Economic Research Service, Washington, DC.

Dixon, P., and M. Rimmer. 2002. Dynamic General Equilibrium Modelling for Forecasting and Policy. North Holland.

Dudu, H., and S. Chumi. 2008. "Economics of Irrigation Water Management: A Literature Survey with Focus on Partial and General Equilibrium Models.” Policy Research Working Paper 4556. World Bank, Washington, DC.

Falloon, P.D., and R.A. Betts. 2006. “The impact of climate change on global river flow in HadGEMI simulations.” Atmos. Sci. Let. 7: 62-68.

Falloon, P.D., and R.A. Betts. 2009. “Climate impacts on European agriculture and water management in the context of adaptation and mitigation - The importance of an integrated approach.” Science of the Total Environment doi:10.1016/j.scitotenv.2009.05.002.

Fischer, G., F.N. Tubiello, H. van Velthuizen, and D.A. Wiberg. 2007. “Climate change impacts on irrigation water requirements: Effects of mitigation, 1990-2080.” Technological Forecasting \& Social Change 74: 1083-1107.

Fischer, G., K. Frohberg, M.L. Parry, and C. Rosenzweig. 1994. "Climate change and world food supply, demand and trade: Who benefits, who loses?” Global Environmental Change 4(1):7-23.

Fischer, G., K. Frohberg, M.L. Parry, and C. Rosenzweig. 1996. "Impacts of potential climate change on global and regional food production and vulnerability”, in E.T. Downing, ed, Climate change and world food security. Springer-Verlag, Berlin.

Fischer, G., M. Shah, F.N. Tubiello, and H. van Velhuizen. 2005. "Socio-economic and climate change impacts on agriculture: an integrated assessment, 1990-2080.” Phil. Trans. R. Soc. B 360: 2067-2083.

Gedney N, P.M. Cox, R.A. Betts, O. Boucher, C. Huntingford, and P.A. Stott. 2006. "Detection of a direct carbon dioxide effect in continental river runoff records." Nature 439(7078): 835-8.

Hertel, T.W. 1997. Global Trade Analysis: Modeling and Applications. Cambridge University Press, Cambridge.

IPCC. 2000. Special Report on Emission Scenario. A Special Report of Working Group III of the IPCC. Cambridge University Press, Cambridge, UK, pp 612.

IPCC. 2001a. Climate Change 2001: Impacts, Adaptation and Vulnerability. Contribution of Working Group II to the Third Assessment Report of the IPCC. J.J. McCarthy, O.F. 
Canziani, N.A. Leary, D.J. Dokken and K.S. White, eds. Cambridge University Press, UK. pp 1000.

IPCC. 2001b. Climate Change 2001: The Scientific Basis. Contribution of Working Group I to the Third Assessment Report of the IPCC. J.T. Houghton, Y. Ding, D.J. Griggs, M. Noguer, J. van der Linden, X. Dai, K. Maskell and, C.A. Johnson, eds. Cambridge University Press, UK. pp. 944.

IPCC. 2007. Climate Change 2007: Impacts, Adaptation and Vulnerability. Contribution of Working Group II to the Fourth Assessment Report of the IPCC. M.L. Parry, O.F. Canziani, J.P. Palutikof, P.J. van der Linden and C.E. Hanson, eds. Cambridge University Press, Cambridge, UK, pp. 976.

Jin, Z.Q., and D.W Zhu. 2008. "Impacts of changes in climate and its variability on foos production in Northeast China.” Acta Agronomica Sinica 34(9): 1588-1597.

Johansson, R.C., Y. Tsur, T.L. Roe, R. Doukkali, and A. Dinar. 2002. "Pricing irrigation water: a review of theory and practice.” Water Policy 4 (2): 173-199.

Johns, T.C., C.F. Durman, H.T. Banks, M.J. Roberts, A.J. McLaren, J.K. Ridley, C.A. Senior, K.D. Williams, A. Jones, G.J. Rickard, S. Cusack, W.J. Ingram, M. Crucifix, D.M.H. Sexton, M.M. Joshi, B-W Dong, H. Spencer, R.S.R. Hill, J.M. Gregory, A.B. Keen, A.K. Pardaens, J.A. Lowe, A. Bodas-Salcedo, S. Stark, and Y. Searl. 2006. “The new Hadley Centre climate model HadGEM1: evaluation of coupled simulations.” Journal of Climate 19: 1327-1353.

Kane, S., J.M. Reilly, and J. Tobey. 1992. “An Empirical Study of the Economic Effects of Climate Change on World Agriculture.” Climatic Change 21: 17-35.

Long, S.P., E.A., Ainsworth, A.D.B., Leakey, J. Nösberger, and D.R. Ort. 2006. "Food for Thought: Lower-Than-Expected Crop Yield Stimulation with Rising $\mathrm{CO}_{2}$ Concentrations.” Science 312(5782): 1918-1921.

Macleod C.J.A., P.D. Falloon, R. Evans, and P.M. Haygarth. 2010. "Effects of climate change on the mobilization of diffuse substances from agricultural systems. Soil Use and Management.” (Submitted).

Martin, G.M., M.A. Ringer, V.D. Pope, A. Jones, C. Dearden, and T.J. Hinton. 2006. "The physical properties of the atmosphere in the new Hadley Centre Global Environmental Model, HadGEM1. Part 1: model description and global climatology.” Journal of Climate 19: 1274-1301. 
McDonald, S., S. Robinson, and K. Thierfelder. 2005. “A SAM Based Global CGE Model using GTAP Data.” Sheffield Economics Research Paper 2005:001. The University of Sheffield.

McKibbin, W.J., and P.J. Wilcoxen. 1998. "The Theoretical and Empirical Structure of the GCubed Model.” Economic Modelling 16(1):123-48.

Milly, P.C.D., K.A. Dunne, and V. Vecchia. 2005. “Global pattern of trends in streamflow and water availability in a changing climate.” Nature 438: 347-350.

Parry, M.L., C. Rosenzweig, A. Iglesias, G. Fischer, and M. Livermore. 1999. "Climate change and world food security: A new assessment.” Global Environmental Change 9: 51-67.

Reilly, J.M., N. Hohmann, and S. Kane. 1994. "Climate Change and Agricultural Trade: Who Benefits, Who Loses?” Global Environmental Change 4 (1): 24-36.

Reilly, J., F. Tubiello, B. McCarl, D. Abler, R. Darwin, K. Fuglie, S. Hollinger, C. Izaurralde, S. Jagtap, J. Jones, L. Learns, D. Ojima, E. Paul, K. Paustian, S. Riha, N. Rosenberg, and C. Rosenzweig. 2003. "U.S. agriculture and climate change: New results.” Climatic Change, 57: 43-69.

Rosegrant, M.W., X. Cai, and S.A. Cline. 2002. World Water and Food to 2025: Dealing With Scarcity. International Food Policy Research Institute. Washington, D.C.

Rosenzweig, C., and A. Iglesias, eds. 1994. Implications of climate change for international agriculture: Crop modelling study. United States Environmental Protection Agency, Washington, DC.

Rosenzweig, C., K.M. Strzepek, D.C. Major, A. Iglesias, D.N. Yates, A. McCluskey, and D. Hillel. 2004. "Water resources for agriculture in a changing climate: International case studies.” Global Environmental Change 14: 345-360.

Rosenzweig, C., and M.L. Parry. 1994. "Potential Impact of Climate Change on World Food Supply.” Nature 367: 133-138.

Stott P.A., G.S. Jones, J.A. Lowe, P. Thorne, C.F. Durman, T.C. Johns, and J-C Thelen. 2006. "Transient climate simulations with the HadGEM1 climate model: causes of past warming and future climate change.” Journal of Climate 19: 2763-2782.

Strzepek, K., and A. McCluskey. 2007. “The Impacts of Climate Change on Regional Water Resources and Agriculture in Africa.” Policy Research Working Paper 4290. World Bank, Washington, DC. 
Tsigas, M.E., G.B. Frisvold, and B. Kuhn. 1997. “Global Climate Change and Agriculture”, in T.W. Hertel, ed., Global Trade Analysis: Modeling and Applications. Cambridge Univiversity Press, Cambridge, pp. 280-301.

Tubiello, F.N., and G. Fischer. 2007. "Reducing climate change impacts on agriculture: Global and regional effects of mitigation, 2000-2080.” Technological Forecasting \& Social Change 74: 1030-1056.

Tubiello, F.N., J.S. Amthor, K.J. Boote, M. Donatelli, W. Easterling, G. Fischer, R.M. Gifford, M. Howden, J. Reilly, and C. Rosenzweig. 2007. “Crop response to elevated $\mathrm{CO}_{2}$ and world food supply. A comment on "Food for Thought ..." by Long et al., Science 312:1918-1921, 2006.” Europ. J. Agronomy 26: 215-223.

United Nations. 1993. The System of National Accounts (SNA93). United Nations, New York. United Nations. 2003. Water for People, Water for Life. The United Nations World Water Development Report, UNESCO-World Water Assessment Programme and Berghahn Books, Paris.

United Nations. 2004. World Population to 2300. Population Division, Department of Economic and Social Affairs, United Nations, New York.

Verburg, P.H., B. Eickhout, and H. van Meijl. 2008. “A multi-scale, multi-model approach for analyzing the future dynamics of European land use.” Ann Reg Sci 42: 57-77.

World Bank. 2007. World development report 2008: Agriculture for development. World Bank, Washington, DC. 

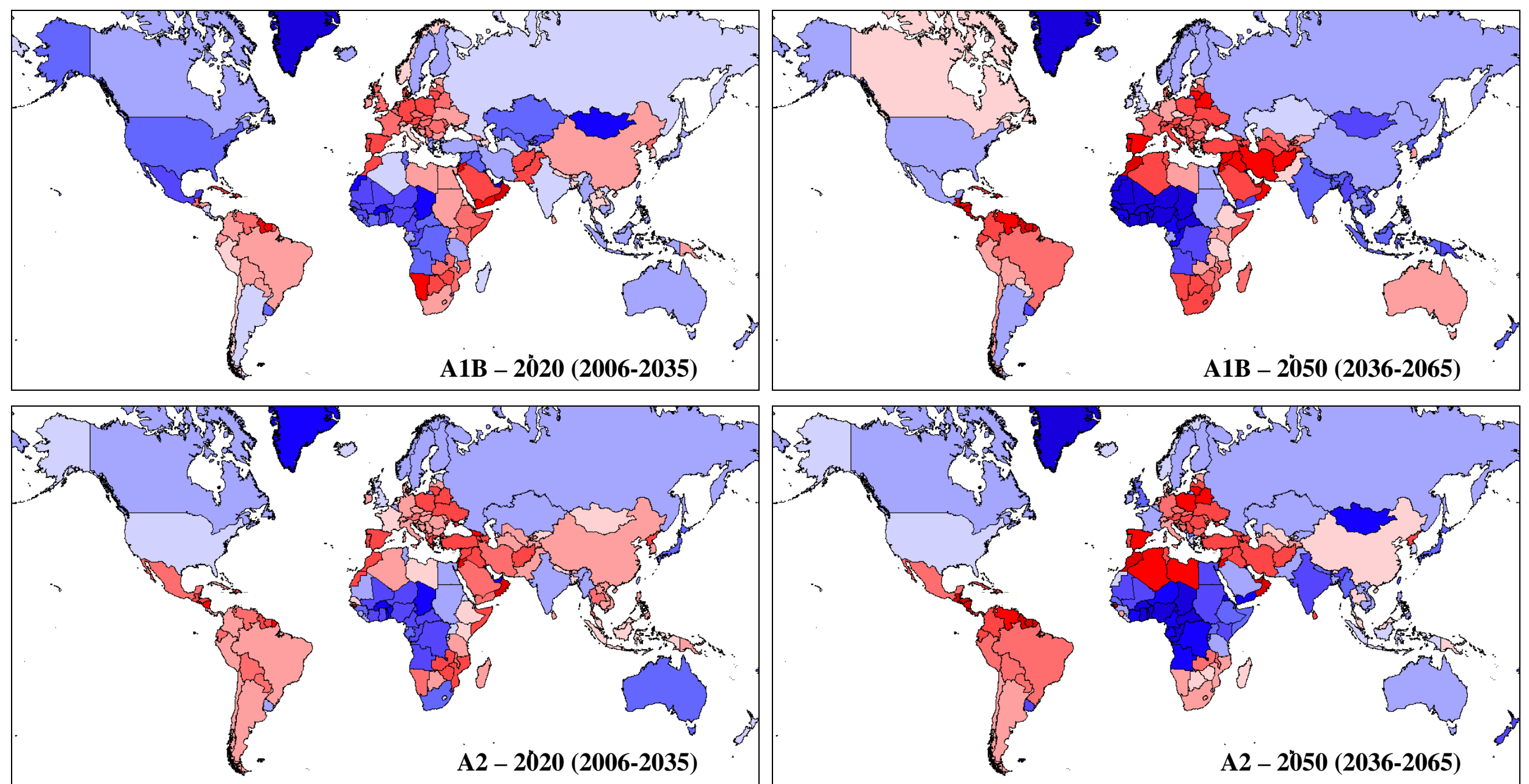

$100-50-30-15-9-3 \quad 0030153050250$

Figure 1. Percentage change in annual average river flow under the two emission scenarios and for the two time periods, with respect to the 30-year average for the 1961-1990 period (historic-anthropogenic simulation)

Own calculations based on Falloon and Betts (2006). 

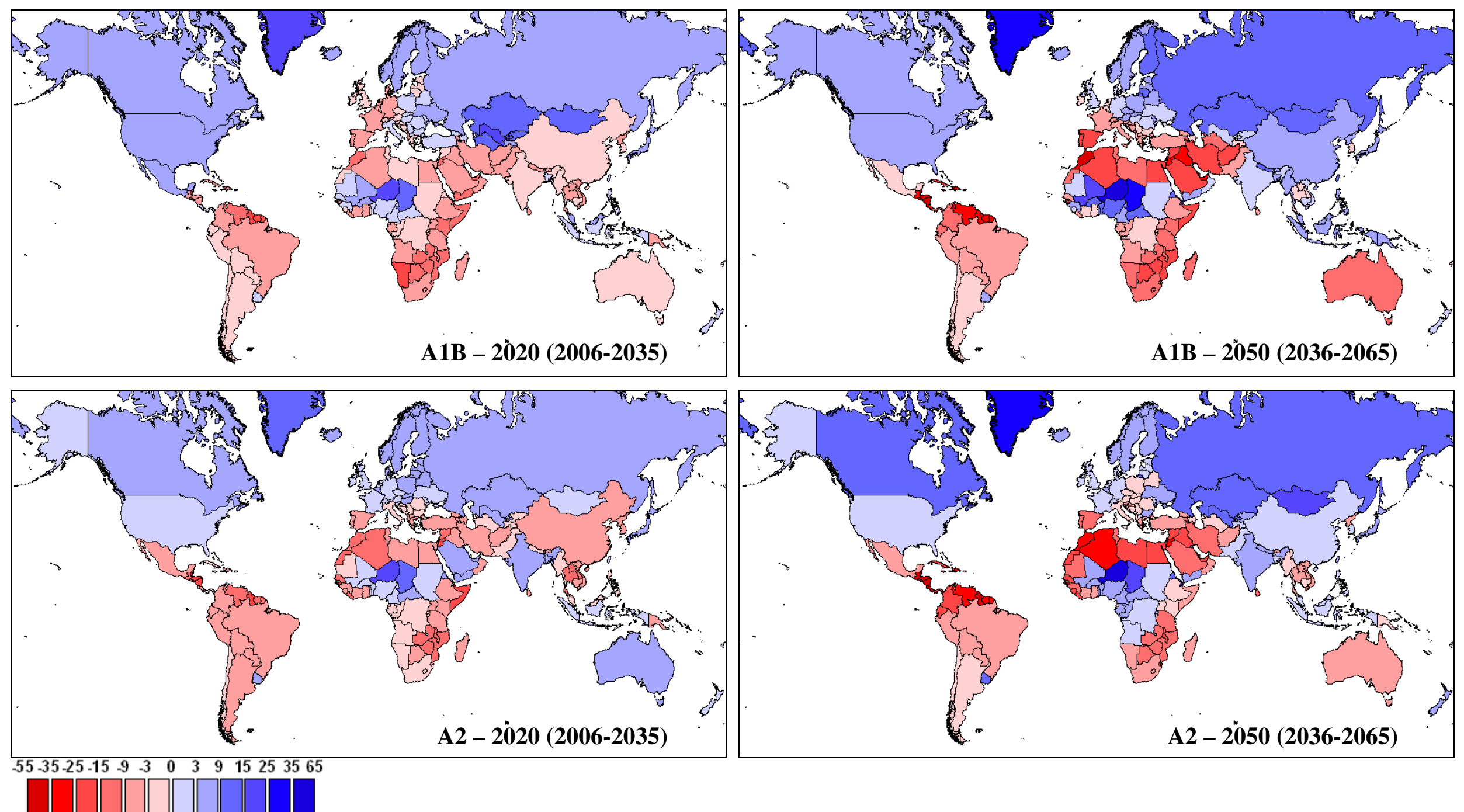

Figure 2. Percentage change in annual average precipitation under the two emission scenarios and for the two time periods, with respect to the 30-year average for the 1961-1990 period (historic-anthropogenic simulation)

Own calculations based on Falloon and Betts (2006). 

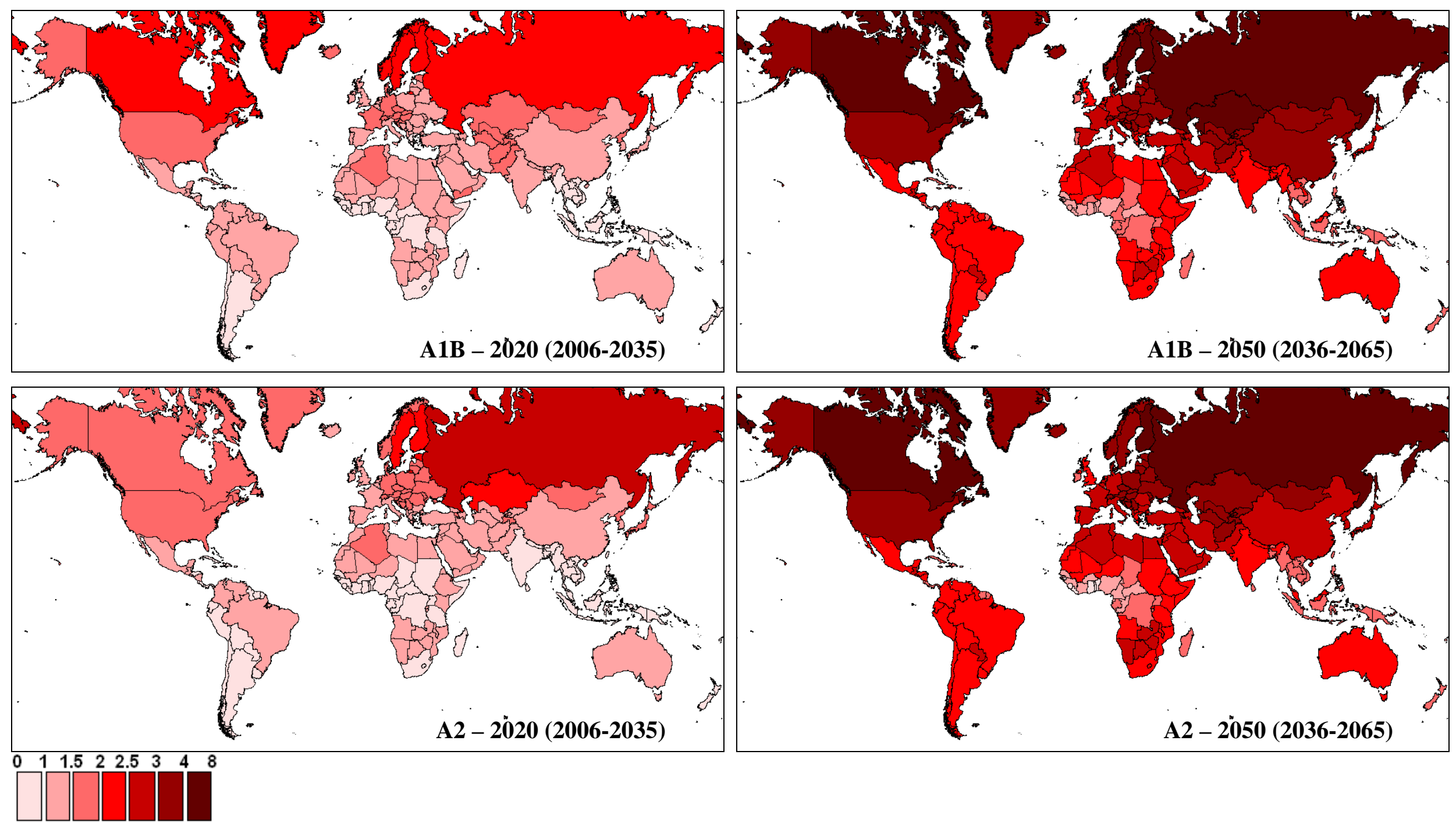

Figure 3. Percentage change in annual average temperature under the two emission scenarios and for the two time periods, with respect to the 30-year average for the 1961-1990 period (historic-anthropogenic simulation) Own calculations based on Falloon and Betts (2006). 


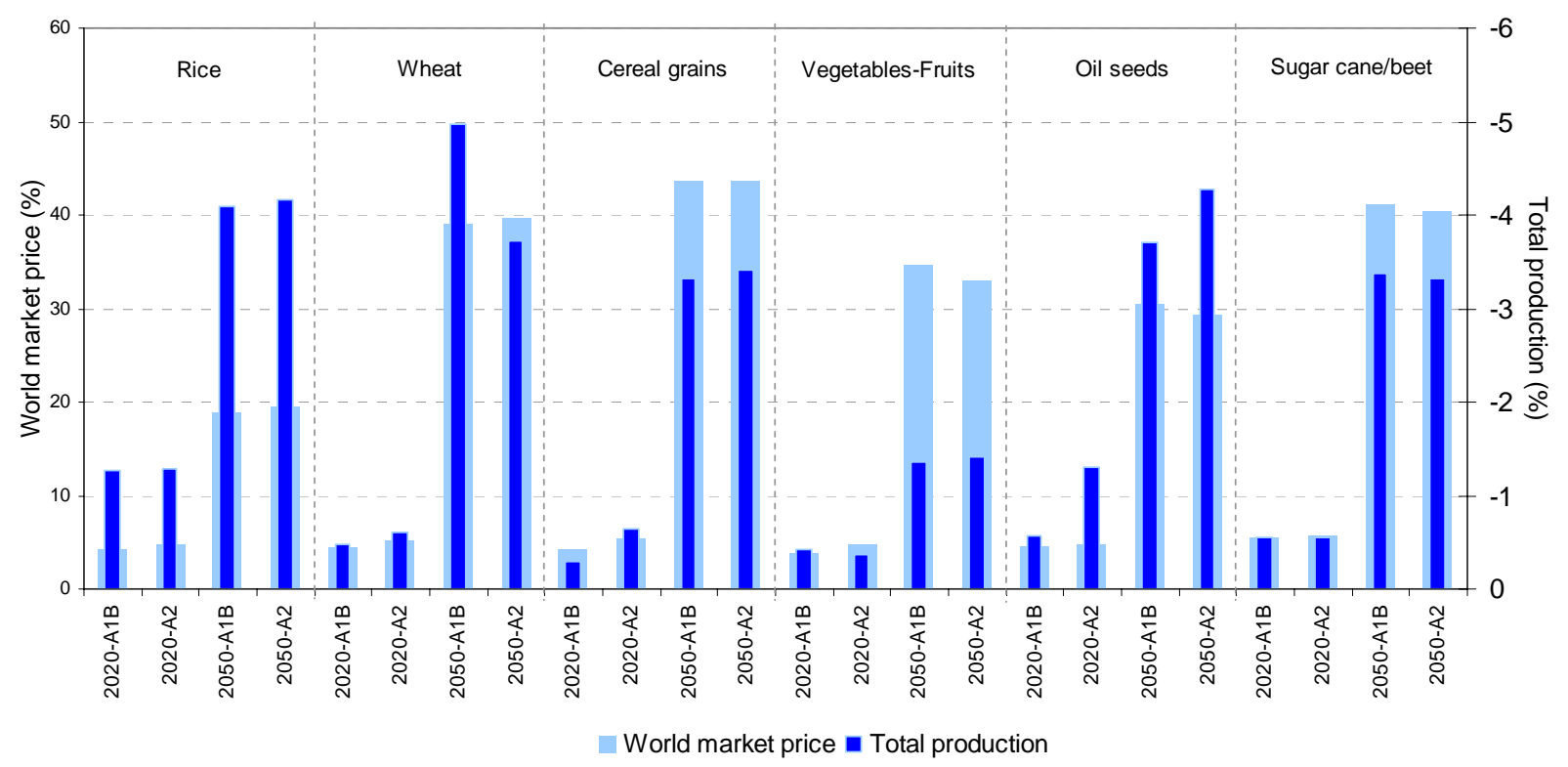

Figure 4. Changes in total agricultural production and world market price by crop, allfactors scenario

Own calculations. 


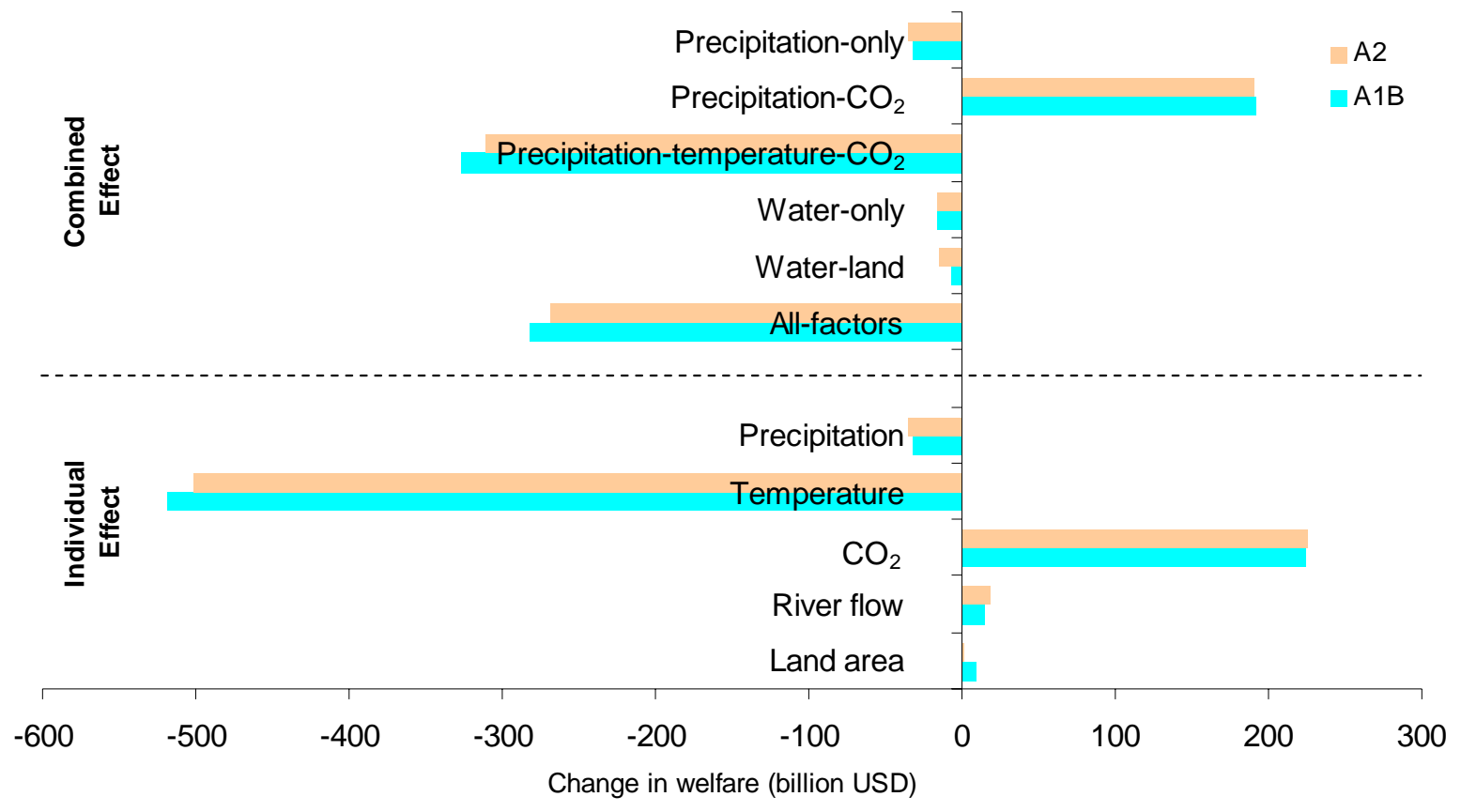

Figure 5. Changes in global welfare by scenario (combined effect) and input variable (individual effect), results for the 2050's

Individual effects on welfare are computed as follows: Precipitation is the precipitation-only scenario. Temperature is the difference between the precipitation-temperature- $\mathrm{CO}_{2}$ and precipitation- $\mathrm{CO}_{2}$ scenarios. Carbon dioxide fertilization $\left(\mathrm{CO}_{2}\right)$ is the difference between the precipitation- $\mathrm{CO}_{2}$ and precipitation-only scenarios. River flow is the difference between the water-only and precipitation-only scenarios. Irrigated land area is the difference between the water-land and water-only scenarios. 

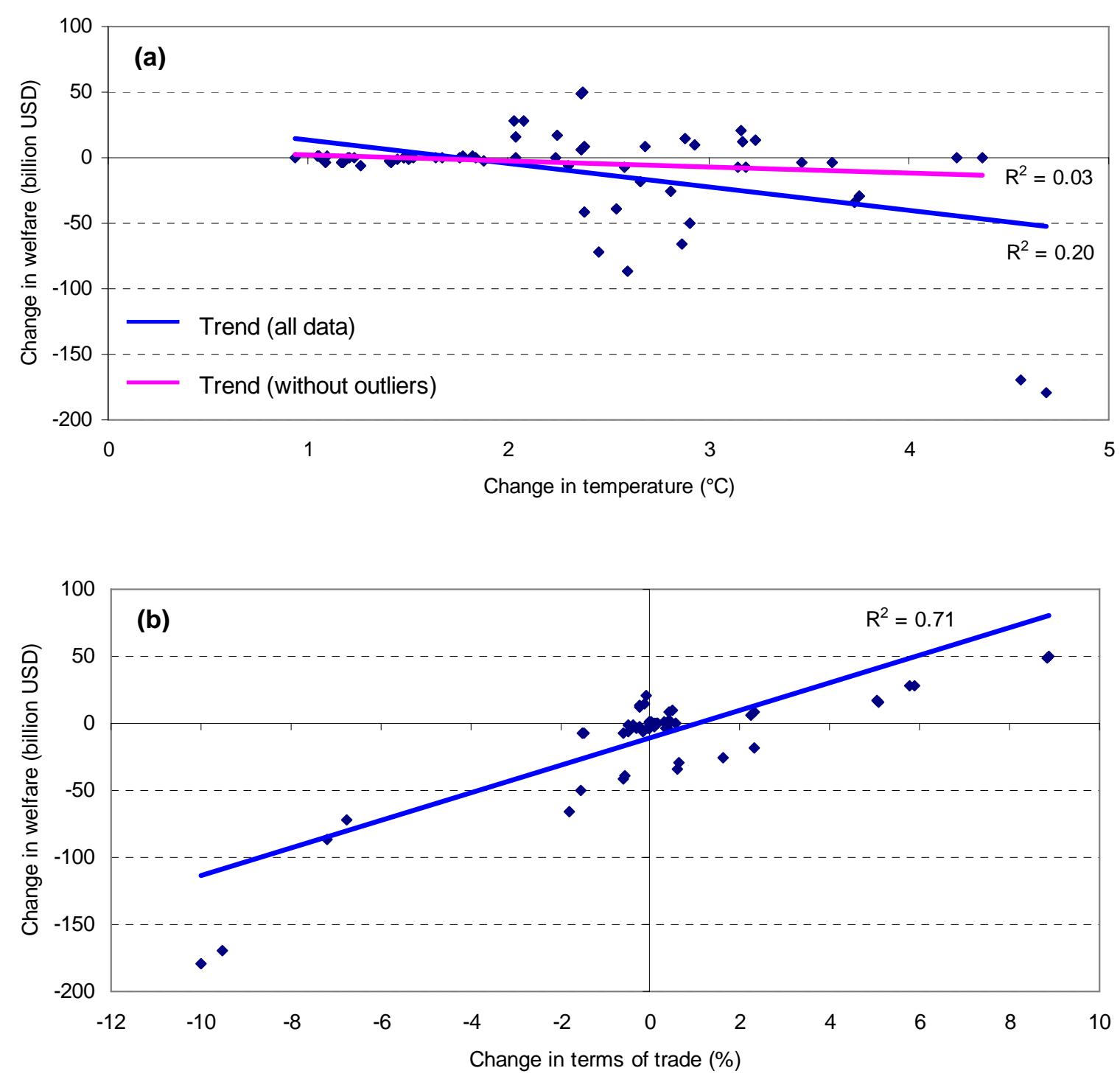

Figure 6. Changes in regional welfare as a function of temperature and the terms of trade, all-factors scenario 
Table 1. Percentage change in regional river flow, water supply, precipitation and temperature with respect to the average over the 1961-1990 period

\begin{tabular}{|c|c|c|c|c|c|c|c|c|c|c|c|c|c|c|c|c|c|}
\hline \multirow{3}{*}{ Regions } & \multirow{3}{*}{$\begin{array}{l}\text { Elasticity } \\
\text { of water } \\
\text { supply* }\end{array}$} & \multicolumn{4}{|c|}{ Changes in river flow (\%) } & \multicolumn{4}{|c|}{ Changes in water supply (\%) } & \multicolumn{4}{|c|}{ Changes in precipitation (\%) } & \multicolumn{4}{|c|}{ Changes in temperature $\left({ }^{\circ} \mathrm{C}\right)$} \\
\hline & & \multicolumn{2}{|c|}{$2020 \mathrm{~s}$} & \multicolumn{2}{|c|}{ 2050s } & \multicolumn{2}{|c|}{ 2020s } & \multicolumn{2}{|c|}{$2050 \mathrm{~s}$} & \multicolumn{2}{|c|}{ 2020s } & \multicolumn{2}{|c|}{ 2050s } & \multicolumn{2}{|c|}{ 2020s } & \multicolumn{2}{|c|}{ 2050s } \\
\hline & & A1B & A2 & A1B & A2 & A1B & A2 & A1B & A2 & A1B & A2 & A1B & A2 & A1B & A2 & A1B & A2 \\
\hline United States & 0.469 & 11.60 & 3.03 & 5.29 & 2.30 & 5.44 & 1.42 & 2.48 & 1.08 & 6.30 & 2.91 & 6.55 & 3.01 & 1.75 & 1.88 & 3.76 & 3.73 \\
\hline Canada & 0.448 & 5.59 & 8.02 & 0.46 & 4.22 & 2.51 & 3.59 & 0.21 & 1.89 & 6.24 & 6.31 & 9.40 & 9.72 & 2.24 & 2.03 & 4.37 & 4.24 \\
\hline Western Europe & 0.342 & -5.81 & -0.77 & -4.21 & -0.46 & -1.99 & -0.26 & -1.44 & -0.16 & 0.68 & 2.07 & 0.25 & 1.48 & 1.82 & 1.78 & 3.24 & 3.17 \\
\hline Japan and South Korea & 0.426 & 7.57 & 7.85 & 11.60 & 10.67 & 3.23 & 3.34 & 4.94 & 4.55 & 4.38 & 4.55 & 6.80 & 5.40 & 1.47 & 1.51 & 2.93 & 2.68 \\
\hline Australia and New Zealand & 0.341 & 6.82 & 11.67 & -5.05 & 6.10 & 2.33 & 3.98 & -1.72 & 2.08 & -0.08 & 4.91 & -8.92 & -6.13 & 1.05 & 1.10 & 2.04 & 2.24 \\
\hline Eastern Europe & 0.299 & -11.60 & -8.03 & -11.92 & -16.52 & -3.47 & -2.40 & -3.57 & -4.94 & 1.22 & 1.70 & 2.52 & -0.32 & 1.49 & 1.64 & 3.19 & 3.14 \\
\hline Former Soviet Union & 0.453 & 2.68 & 3.62 & 7.76 & 8.18 & 1.21 & 1.64 & 3.52 & 3.71 & 7.08 & 8.59 & 13.76 & 12.97 & 2.30 & 2.58 & 4.69 & 4.56 \\
\hline Middle East & 0.223 & 8.31 & -20.18 & -32.61 & -23.84 & 1.85 & -4.50 & -7.27 & -5.32 & -2.18 & -4.13 & -12.84 & -8.93 & 1.40 & 1.42 & 2.87 & 2.91 \\
\hline Central America & 0.318 & 16.17 & -10.28 & -5.85 & -19.85 & 5.14 & -3.27 & -1.86 & -6.31 & 2.83 & -5.49 & -9.35 & -15.39 & 1.23 & 1.19 & 2.38 & 2.36 \\
\hline South America & 0.318 & -3.97 & -6.51 & -9.08 & -12.41 & -1.26 & -2.07 & -2.89 & -3.95 & -3.70 & -4.69 & -7.87 & -8.90 & 1.21 & 1.05 & 2.37 & 2.37 \\
\hline South Asia & 0.279 & -3.91 & -0.33 & 11.16 & 8.99 & -1.09 & -0.09 & 3.11 & 2.51 & -1.78 & 1.60 & 1.56 & 2.62 & 1.26 & 1.08 & 2.60 & 2.45 \\
\hline Southeast Asia & 0.324 & 4.04 & -0.72 & 13.91 & 5.54 & 1.31 & -0.23 & 4.51 & 1.80 & 2.10 & -0.84 & 5.17 & 1.03 & 1.18 & 1.17 & 2.54 & 2.38 \\
\hline China & 0.412 & -6.07 & -7.64 & 8.78 & -0.67 & -2.50 & -3.15 & 3.62 & -0.27 & -1.94 & -3.32 & 6.22 & 1.91 & 1.48 & 1.52 & 3.16 & 2.88 \\
\hline North Africa & 0.223 & -3.16 & 7.66 & 6.99 & 20.07 & -0.70 & 1.71 & 1.56 & 4.48 & -5.61 & -9.24 & -22.56 & -25.27 & 1.44 & 1.50 & 2.66 & 2.81 \\
\hline Sub-Saharan Africa & 0.223 & 4.42 & 9.75 & 17.78 & 25.26 & 0.99 & 2.17 & 3.97 & 5.63 & -3.82 & -2.45 & -2.88 & -1.49 & 1.06 & 0.94 & 2.08 & 2.03 \\
\hline Rest of the World & 0.324 & -4.22 & -4.29 & 15.91 & 0.27 & -1.37 & -1.39 & 5.15 & 0.09 & -1.13 & -0.69 & 8.31 & 0.52 & 1.83 & 1.67 & 3.62 & 3.47 \\
\hline
\end{tabular}

Source: Own calculation based on Falloon and Betts (2006).

* Regional elasticities of water supply are based on Darwin et al. (1995). 
Table 2. Summary of inputs for the simulation scenarios

\begin{tabular}{|l|ccccc|}
\hline & Precipitation & $\mathbf{C O}_{2}$ & $\begin{array}{c}\text { Changes in } \\
\text { Temperature }\end{array}$ & River flow & Land \\
\hline Scenario & & & & & \\
Precipitation-only & $\mathrm{X}$ & & & & \\
Precipitation- $\mathrm{CO}_{2}$ & $\mathrm{X}$ & $\mathrm{X}$ & & & \\
Precipitation-temperature- $\mathrm{CO}_{2}$ & $\mathrm{X}$ & $\mathrm{X}$ & $\mathrm{X}$ & & \\
Water-only & $\mathrm{X}$ & & & $\mathrm{X}$ & \\
Water-land & $\mathrm{X}$ & & & $\mathrm{X}$ & $\mathrm{X}$ \\
All-factors & $\mathrm{X}$ & $\mathrm{X}$ & $\mathrm{X}$ & $\mathrm{X}$ & $\mathrm{X}$ \\
\hline
\end{tabular}


Table 3. Percentage change in total crop production for the two time periods and SRES scenarios by region and simulation scenario, percentage change with respect to the baseline (no climate change) simulations

\begin{tabular}{|c|c|c|c|c|c|c|c|c|c|c|c|c|c|}
\hline \multirow{2}{*}{ Regions } & \multirow{2}{*}{$\begin{array}{c}\text { Baseline } \\
\text { (thousand mt) }\end{array}$} & \multicolumn{2}{|c|}{ Precipitation-only } & \multicolumn{2}{|c|}{ Precipitation- $\mathrm{CO}_{2}$} & \multicolumn{2}{|c|}{ Precip.-Temp.-CO ${ }_{2}$} & \multicolumn{2}{|c|}{ Water-only } & \multicolumn{2}{|c|}{ Water-land } & \multicolumn{2}{|c|}{ All-factors } \\
\hline & & & & & & & & A1B & A2 & A1B & A2 & A1B & A2 \\
\hline Results for the 2020s & & & & & & & & & & & & & \\
\hline United States & 873,944 & 1.50 & 0.76 & 2.02 & 1.34 & -2.06 & -3.59 & 0.97 & 0.29 & 2.03 & 0.72 & -1.61 & -3.73 \\
\hline Canada & 88,699 & 3.23 & 3.88 & -0.67 & 0.08 & -1.31 & 0.44 & 3.19 & 3.50 & 2.53 & 3.58 & -2.02 & -0.05 \\
\hline Western Europe & 638,485 & -0.06 & 0.23 & -0.22 & 0.04 & 2.39 & 2.81 & -0.12 & 0.13 & -0.33 & 0.18 & 2.09 & 2.72 \\
\hline Japan and South Korea & 97,299 & 0.03 & 0.14 & -0.12 & -0.01 & 0.54 & 0.63 & 0.10 & 0.22 & 0.51 & 0.76 & 1.08 & 1.31 \\
\hline Australia and New Zealand & 118,733 & -0.40 & 3.13 & -0.02 & 3.11 & 7.25 & 11.07 & -0.28 & 2.77 & -0.44 & 2.89 & 7.16 & 10.76 \\
\hline Eastern Europe & 263,636 & 0.08 & 0.16 & 1.77 & 1.77 & 1.59 & 1.50 & 0.04 & 0.11 & -0.09 & 0.05 & 1.41 & 1.38 \\
\hline Former Soviet Union & 410,215 & 0.44 & 0.60 & 0.53 & 0.66 & -4.04 & -4.77 & 0.34 & 0.46 & 0.34 & 0.52 & -4.19 & -4.95 \\
\hline Middle East & 340,539 & -1.64 & -2.92 & -2.01 & -3.05 & -2.19 & -3.93 & -1.31 & -2.47 & -1.36 & -2.69 & -1.83 & -3.62 \\
\hline Central America & 299,744 & -0.05 & -0.33 & 0.49 & 0.23 & -0.18 & -0.42 & 0.16 & -0.29 & 0.50 & -0.64 & 0.42 & -0.75 \\
\hline South America & $1,496,931$ & -0.19 & -0.13 & -0.16 & -0.11 & -0.06 & 0.21 & -0.17 & -0.13 & -0.24 & -0.15 & -0.12 & 0.19 \\
\hline South Asia & $1,373,835$ & 0.00 & 0.32 & 1.44 & 1.66 & -1.67 & -0.77 & -0.04 & 0.20 & -0.18 & 0.19 & -1.87 & -0.92 \\
\hline Southeast Asia & 713,486 & 0.81 & 0.03 & 3.89 & 3.01 & -5.47 & -6.40 & 0.72 & 0.01 & 0.81 & 0.02 & -5.48 & -6.41 \\
\hline China & $1,705,822$ & -0.39 & -0.51 & -0.16 & -0.25 & 2.50 & 2.38 & -0.40 & -0.42 & -0.96 & -1.05 & 1.86 & 1.77 \\
\hline North Africa & 180,359 & -1.53 & -2.68 & -2.11 & -2.97 & -1.67 & -3.42 & -0.46 & -0.67 & -0.54 & -0.52 & -0.29 & -0.42 \\
\hline Sub-Saharan Africa & 751,022 & -0.26 & -0.07 & -0.66 & -0.49 & 0.83 & 1.27 & -0.26 & -0.10 & -0.29 & -0.04 & 0.79 & 1.29 \\
\hline Rest of the World & 113,851 & -0.09 & -0.04 & 0.47 & 0.50 & -1.36 & -1.05 & -0.10 & -0.05 & -0.15 & -0.07 & -1.41 & -1.09 \\
\hline Results for $t$ & & & & & & & & & & & & & \\
\hline United States & $1,232,174$ & 3.02 & 1.80 & 5.88 & 4.86 & -8.04 & -9.36 & 1.33 & 0.75 & 2.06 & 1.16 & -9.20 & -10.12 \\
\hline Canada & 106,975 & 12.56 & 13.23 & 9.11 & 9.75 & -7.48 & -5.87 & 10.37 & 10.62 & 9.96 & 10.69 & -10.04 & -8.53 \\
\hline Western Europe & 640,851 & 1.34 & 1.45 & 4.07 & 4.22 & 4.83 & 5.02 & 0.90 & 1.03 & 0.68 & 1.09 & 4.30 & 4.83 \\
\hline Japan and South Korea & 99,685 & 1.63 & 1.59 & 0.43 & 0.47 & 4.92 & 5.23 & 1.59 & 1.58 & 2.91 & 3.06 & 6.47 & 6.86 \\
\hline Australia and New Zealand & 158,200 & -9.25 & -5.76 & -4.08 & -1.12 & 6.98 & 9.99 & -8.56 & -5.61 & -8.80 & -5.61 & 6.95 & 9.49 \\
\hline Eastern Europe & 302,068 & 0.61 & 0.23 & 6.67 & 6.35 & 2.92 & 2.68 & 0.45 & 0.05 & 0.31 & -0.13 & 2.59 & 2.29 \\
\hline Former Soviet Union & 555,515 & 3.00 & 2.94 & 4.62 & 4.61 & -20.91 & -20.07 & 2.35 & 2.25 & 2.52 & 2.48 & -21.28 & -20.42 \\
\hline Middle East & 490,596 & -17.47 & -11.22 & -12.61 & -7.95 & -24.10 & -17.12 & -16.48 & -10.82 & -16.84 & -11.05 & -23.24 & -16.81 \\
\hline Central America & 481,010 & -0.52 & -0.87 & 1.56 & 1.32 & -1.64 & -2.03 & -0.39 & -0.68 & -0.64 & -1.52 & -1.70 & -2.70 \\
\hline South America & $2,905,101$ & -0.24 & -0.26 & 1.21 & 1.23 & -1.84 & -1.82 & -0.24 & -0.26 & -0.28 & -0.34 & -1.77 & -1.81 \\
\hline South Asia & $1,932,186$ & 0.82 & 1.20 & 4.98 & 5.24 & -3.14 & -1.96 & 0.70 & 0.93 & 0.82 & 1.08 & -3.16 & -2.17 \\
\hline Southeast Asia & $1,054,256$ & 2.60 & 0.69 & 10.68 & 8.89 & -11.86 & -12.54 & 2.39 & 0.62 & 2.75 & 0.83 & -11.63 & -12.28 \\
\hline China & $1,992,463$ & 1.67 & 1.02 & 4.11 & 3.64 & 10.07 & 9.89 & 1.51 & 0.40 & 2.50 & 0.27 & 11.18 & 9.04 \\
\hline North Africa & 272,933 & -19.87 & -23.70 & -16.33 & -18.87 & -25.75 & -31.91 & -7.22 & -9.60 & -7.27 & -9.26 & -8.90 & -13.73 \\
\hline Sub-Saharan Africa & $1,245,619$ & 0.99 & 1.05 & 0.76 & 0.84 & 3.91 & 4.02 & 0.58 & 0.59 & 0.55 & 0.66 & 3.54 & 3.69 \\
\hline Rest of the World & 195,251 & 0.23 & 0.00 & 2.26 & 2.11 & -3.78 & -3.73 & 0.24 & 0.01 & 0.31 & 0.01 & -3.58 & -3.64 \\
\hline
\end{tabular}


Table 4. Percentage change in total water use in agricultural production for the two time periods and SRES scenarios by region and simulation scenario, percentage change with respect to the baseline (no climate change) simulations

\begin{tabular}{|c|c|c|c|c|c|c|c|c|c|c|c|c|c|}
\hline \multirow[t]{2}{*}{ Regions } & \multirow{2}{*}{$\begin{array}{c}\text { Baseline } \\
\left(\mathbf{k m}^{3}\right)\end{array}$} & \multicolumn{2}{|c|}{ Precipitation-only } & \multicolumn{2}{|c|}{ Precipitation-CO${ }_{2}$} & \multicolumn{2}{|c|}{ Precip.-Temp.-CO } & \multicolumn{2}{|c|}{ Water-only } & \multicolumn{2}{|c|}{ Water-land } & \multicolumn{2}{|c|}{ All-factors } \\
\hline & & A1B & $\mathbf{A} 2$ & A1 & A2 & A1B & A2 & A1B & A2 & A1B & A2 & A1B & A2 \\
\hline Results for the 2020s & & & & & & & & & & & & & \\
\hline United States & 520 & 2.19 & 1.06 & 3.80 & 2.67 & -3.45 & -5.61 & 1.33 & 0.32 & 3.21 & 0.97 & -2.65 & -5.82 \\
\hline Canada & 67 & 3.42 & 4.07 & -0.36 & 0.39 & -1.62 & 0.18 & 3.36 & 3.73 & 2.69 & 3.79 & -2.27 & -0.23 \\
\hline Western Europe & 115 & -0.11 & 0.20 & -0.23 & 0.04 & 3.02 & 3.45 & -0.19 & 0.09 & -0.50 & 0.12 & 2.60 & 3.32 \\
\hline Japan and South Korea & 33 & -0.21 & -0.02 & -0.81 & -0.63 & 1.17 & 1.43 & -0.14 & 0.00 & -0.16 & 0.16 & 1.35 & 1.76 \\
\hline Australia and New Zealand & 70 & -0.56 & 5.62 & 1.40 & 7.10 & 11.27 & 17.91 & -0.21 & 3.85 & -0.08 & 4.59 & 11.76 & 16.85 \\
\hline Eastern Europe & 130 & 0.08 & 0.16 & 2.12 & 2.10 & 1.89 & 1.78 & -0.09 & 0.01 & -0.57 & -0.30 & 1.22 & 1.30 \\
\hline Former Soviet Union & 278 & 0.73 & 0.96 & 1.31 & 1.48 & -5.87 & -6.82 & 0.36 & 0.49 & 0.46 & 0.70 & -6.21 & -7.21 \\
\hline Middle East & 147 & -3.89 & -7.04 & -2.49 & -5.46 & -6.80 & -10.56 & -1.48 & -3.69 & -1.07 & -5.47 & -3.94 & -8.81 \\
\hline Central America & 157 & -0.03 & -0.54 & 1.48 & 0.94 & -0.72 & -1.15 & 0.54 & -0.43 & 1.50 & -1.35 & 0.81 & -1.96 \\
\hline South America & 565 & -0.48 & -0.33 & -0.50 & -0.37 & 0.04 & 0.67 & -0.41 & -0.29 & -0.65 & -0.43 & -0.13 & 0.57 \\
\hline South Asia & 1,410 & 0.03 & 0.50 & 2.64 & 2.96 & -2.74 & -1.47 & -0.13 & 0.12 & -0.49 & 0.10 & -3.26 & -1.88 \\
\hline Southeast Asia & 627 & 0.74 & 0.00 & 3.54 & 2.72 & -5.27 & -6.17 & 0.68 & -0.01 & 0.69 & -0.05 & -5.33 & -6.23 \\
\hline China & 1,031 & -0.50 & -0.69 & 0.66 & 0.44 & 2.96 & 2.71 & -0.49 & -0.53 & -1.36 & -1.55 & 2.00 & 1.75 \\
\hline North Africa & 75 & -5.70 & -9.42 & -5.05 & -8.45 & -8.11 & -12.66 & -0.64 & -0.64 & -0.90 & 0.03 & -2.85 & -2.41 \\
\hline Sub-Saharan Africa & 902 & -0.34 & -0.16 & -0.73 & -0.56 & 0.90 & 1.38 & -0.32 & -0.14 & -0.37 & -0.05 & 0.87 & 1.48 \\
\hline Rest of the World & 29 & -0.12 & -0.05 & 1.40 & 1.40 & -2.73 & -2.26 & -0.12 & -0.07 & -0.44 & -0.35 & -3.03 & -2.55 \\
\hline Total & 6,156 & -0.01 & -0.10 & 1.27 & 1.13 & -1.17 & -1.16 & 0.00 & -0.08 & -0.09 & -0.25 & -1.27 & -1.33 \\
\hline Results for the & & & & & & & & & & & & & \\
\hline United States & 647 & 2.99 & 1.55 & 8.47 & 7.15 & -10.45 & -11.91 & 1.01 & 0.47 & 2.03 & 0.99 & -11.69 & -12.62 \\
\hline Canada & 69 & 12.24 & 12.94 & 9.92 & 10.56 & -8.19 & -6.62 & 10.74 & 11.06 & 10.31 & 11.05 & -9.70 & -8.25 \\
\hline Western Europe & 97 & 1.33 & 1.50 & 4.84 & 5.00 & 5.58 & 5.86 & 0.81 & 0.97 & 0.48 & 1.03 & 4.83 & 5.53 \\
\hline Japan and South Korea & 35 & 1.29 & 1.47 & -0.33 & -0.17 & 5.59 & 5.93 & 1.20 & 1.32 & 2.39 & 2.73 & 6.69 & 7.28 \\
\hline Australia and New Zealand & 78 & -13.69 & -8.76 & -5.10 & -0.36 & 8.52 & 12.92 & -8.79 & -5.64 & -9.41 & -5.23 & 11.86 & 15.46 \\
\hline Eastern Europe & 137 & 0.71 & 0.30 & 7.32 & 6.96 & 3.98 & 3.72 & 0.25 & -0.14 & -0.52 & -1.16 & 2.69 & 2.17 \\
\hline Former Soviet Union & 312 & 3.65 & 3.60 & 5.74 & 5.69 & -22.76 & -21.88 & 2.37 & 2.29 & 2.85 & 2.89 & -23.52 & -22.55 \\
\hline Middle East & 179 & -26.55 & -17.09 & -19.79 & -11.33 & -34.04 & -24.17 & -16.75 & -11.00 & -19.64 & -13.00 & -26.50 & -19.74 \\
\hline Central America & 214 & -1.00 & -1.47 & 2.94 & 2.55 & -2.06 & -2.54 & -0.55 & -0.99 & -1.19 & -2.88 & -2.20 & -3.93 \\
\hline South America & 837 & -0.27 & -0.12 & 0.06 & 0.19 & -0.09 & -0.03 & -0.40 & -0.37 & -0.87 & -0.74 & -0.65 & -0.67 \\
\hline South Asia & 1,881 & 0.87 & 1.35 & 6.61 & 6.93 & -3.88 & -2.54 & 0.82 & 0.97 & 1.31 & 1.44 & -3.46 & -2.49 \\
\hline Southeast Asia & 843 & 2.71 & 0.72 & 10.59 & 8.78 & -12.22 & -12.96 & 2.55 & 0.60 & 2.49 & 0.55 & -12.42 & -13.13 \\
\hline China & 1,249 & 1.80 & 1.00 & 6.46 & 5.82 & 10.64 & 10.51 & 1.72 & 0.32 & 3.10 & 0.16 & 12.16 & 9.46 \\
\hline North Africa & 89 & -36.40 & -41.38 & -28.32 & -33.10 & -43.60 & -50.38 & -4.77 & -5.64 & -4.19 & -3.70 & -8.76 & -10.89 \\
\hline Sub-Saharan Africa & 1,359 & 0.58 & 0.75 & 1.05 & 1.20 & 3.58 & 3.83 & 0.32 & 0.44 & 0.24 & 0.51 & 3.26 & 3.60 \\
\hline Rest of the World & 43 & 0.36 & -0.02 & 4.65 & 4.39 & -5.97 & -5.86 & 0.45 & 0.00 & 1.32 & 0.05 & -5.09 & -5.78 \\
\hline Total & 8,068 & 0.21 & 0.10 & 4.30 & 4.19 & -2.81 & -2.44 & 0.50 & 0.22 & 0.77 & 0.26 & -2.19 & -2.31 \\
\hline
\end{tabular}


Table 5. Changes in regional welfare for two time periods and SRES scenarios by simulation scenario (million USD), changes with respect to the baseline (no climate change) simulations

\begin{tabular}{|c|c|c|c|c|c|c|c|c|c|c|c|c|}
\hline \multirow[t]{2}{*}{ Regions } & \multicolumn{2}{|c|}{ Precipitation-only } & \multicolumn{2}{|c|}{ Precipitation- $\mathrm{CO}_{2}$} & \multicolumn{2}{|c|}{ Precip.-Temp.-CO } & \multicolumn{2}{|c|}{ Water-only } & \multicolumn{2}{|c|}{ Water-land } & \multicolumn{2}{|c|}{ All-factors } \\
\hline & A1B & & & & A1B & & A1B & A2 & A1B & A2 & A1B & A2 \\
\hline Results for the 2020s & & & & & & & & & & & & \\
\hline United States & 718 & 352 & 1,098 & 796 & -931 & $-1,859$ & 571 & 105 & 1,014 & 254 & -606 & $-2,055$ \\
\hline Canada & 61 & 74 & -42 & -32 & -39 & -4 & 65 & 69 & 43 & 65 & -60 & -20 \\
\hline Western Europe & 113 & 32 & 2,542 & 2,379 & 1,138 & 1,420 & 101 & 7 & 200 & -104 & 1,248 & 1,325 \\
\hline Japan and South Korea & 298 & 198 & 1,702 & 1,562 & -168 & -276 & 271 & 182 & 514 & 279 & 55 & -189 \\
\hline Australia and New Zealand & -73 & 134 & -485 & -318 & 781 & 1,023 & -64 & 117 & -92 & 135 & 756 & 1,022 \\
\hline Eastern Europe & 66 & 63 & 1,563 & 1,503 & 678 & 593 & 47 & 50 & 0 & -2 & 618 & 538 \\
\hline Former Soviet Union & 444 & 499 & 1,469 & 1,471 & $-5,515$ & $-6,680$ & 371 & 426 & 406 & 460 & $-5,654$ & $-6,865$ \\
\hline Middle East & -422 & -976 & 834 & 352 & $-2,584$ & $-3,496$ & -305 & -767 & -245 & -878 & $-2,353$ & $-3,344$ \\
\hline Central America & 46 & -25 & 87 & 28 & -86 & -165 & 67 & -37 & 154 & -84 & 46 & -240 \\
\hline South America & -244 & -151 & -721 & -633 & 436 & 828 & -230 & -147 & -334 & -169 & 332 & 805 \\
\hline South Asia & 198 & 885 & 4,968 & 5,338 & $-5,541$ & $-3,292$ & 58 & 630 & -141 & 601 & $-5,948$ & $-3,632$ \\
\hline Southeast Asia & 470 & 70 & 2,209 & 1,806 & $-3,157$ & $-3,759$ & 403 & 44 & 493 & 30 & $-3,137$ & $-3,813$ \\
\hline China & -124 & -336 & 1,843 & 1,596 & 795 & 529 & -116 & -250 & -503 & -819 & 441 & 71 \\
\hline North Africa & -398 & -830 & 22 & -328 & $-1,299$ & $-2,078$ & -93 & -205 & -89 & -177 & -859 & $-1,107$ \\
\hline Sub-Saharan Africa & -89 & -49 & -238 & -204 & 157 & 266 & -92 & -47 & -113 & -32 & 129 & 283 \\
\hline Rest of the World & 2 & 1 & 178 & 171 & -334 & -293 & -2 & -3 & -4 & -11 & -340 & -308 \\
\hline Total & 1,064 & -58 & 17,027 & 15,488 & $-15,669$ & $-17,245$ & 1,053 & 174 & 1,303 & -452 & $-15,333$ & $-17,530$ \\
\hline Results for the 2050s & & & & & & & & & & & & \\
\hline United States & 8,549 & 5,232 & 13,803 & 12,241 & $-22,875$ & $-30,028$ & 3,137 & 1,646 & 4,663 & 2,295 & $-29,695$ & $-34,251$ \\
\hline Canada & 2,937 & 3,209 & -125 & -22 & 1,244 & 1,865 & 2,308 & 2,325 & 2,057 & 2,274 & 22 & 462 \\
\hline Western Europe & $-8,293$ & $-8,657$ & 50,244 & 50,387 & 7,952 & 7,795 & $-6,081$ & $-5,726$ & $-4,622$ & $-6,398$ & 13,627 & 11,767 \\
\hline Japan and South Korea & 1,864 & 1,025 & 15,961 & 15,469 & 6,141 & 6,201 & 1,717 & 1,002 & 4,317 & 2,471 & 9,265 & 8,012 \\
\hline Australia and New Zealand & $-3,131$ & $-1,129$ & $-8,504$ & $-7,685$ & 18,303 & 19,333 & $-3,535$ & $-1,873$ & $-4,003$ & $-1,947$ & 15,560 & 16,912 \\
\hline Eastern Europe & $-3,649$ & $-4,653$ & 26,928 & 26,485 & $-9,300$ & $-9,518$ & $-2,435$ & $-3,129$ & $-2,129$ & $-3,568$ & $-7,011$ & $-7,797$ \\
\hline Former Soviet Union & 6,180 & 5,521 & 25,337 & 24,976 & $-183,783$ & $-173,842$ & 6,103 & 5,757 & 7,161 & 6,601 & $-179,459$ & $-169,498$ \\
\hline Middle East & $-30,700$ & $-19,816$ & $-3,892$ & 1,407 & $-73,756$ & $-54,302$ & $-26,475$ & $-16,681$ & $-26,354$ & $-16,958$ & $-66,360$ & $-49,479$ \\
\hline Central America & 1,687 & 1,228 & $-4,220$ & $-4,446$ & 10,908 & 9,566 & 1,029 & 428 & 458 & -638 & 8,535 & 6,188 \\
\hline South America & 7,919 & 8,898 & $-28,850$ & $-28,467$ & 60,915 & 59,061 & 4,389 & 4,292 & 1,819 & 3,552 & 49,634 & 48,800 \\
\hline South Asia & $-1,252$ & 1,922 & 79,826 & 81,526 & $-94,676$ & $-77,829$ & 1,169 & 3,978 & 3,664 & 4,991 & $-86,006$ & $-72,555$ \\
\hline Southeast Asia & 3,646 & -362 & 23,908 & 21,652 & $-42,111$ & $-43,539$ & 3,577 & 97 & 4,955 & 609 & $-38,809$ & $-41,028$ \\
\hline China & 2,727 & 389 & 24,389 & 23,365 & 17,399 & 17,160 & 2,644 & -559 & 6,398 & -905 & 20,873 & 14,920 \\
\hline North Africa & $-25,704$ & $-33,257$ & $-11,473$ & $-14,585$ & $-53,774$ & $-71,418$ & $-7,444$ & $-10,289$ & $-7,309$ & $-9,876$ & $-17,871$ & $-26,039$ \\
\hline Sub-Saharan Africa & 4,775 & 5,196 & $-13,511$ & $-13,376$ & 33,606 & 32,786 & 2,872 & 2,966 & 1,918 & 2,947 & 27,964 & 28,202 \\
\hline Rest of the World & 256 & 35 & 1,811 & 1,706 & $-3,481$ & $-3,463$ & 255 & 13 & 367 & 8 & $-3,197$ & $-3,405$ \\
\hline Total & $-32,189$ & $-35,220$ & 191,633 & 190,634 & $-327,288$ & $-310,173$ & $-16,771$ & $-15,752$ & $-6,641$ & $-14,542$ & $-282,929$ & $-268,788$ \\
\hline
\end{tabular}


Table 6. Summary of the climate change impacts on agricultural production by simulation scenario, percentage change with respect to the baseline simulations

\begin{tabular}{|c|c|c|c|c|c|c|c|c|c|c|c|c|c|}
\hline \multirow[t]{2}{*}{ Description } & \multirow[t]{2}{*}{ Baseline } & \multicolumn{2}{|c|}{ Precipitation-only } & \multicolumn{2}{|c|}{ Precipitation- $\mathrm{CO}_{2}$} & \multicolumn{2}{|c|}{ Precip.-Temp.-CO } & \multicolumn{2}{|c|}{ Water-only } & \multicolumn{2}{|c|}{ Water-land } & \multicolumn{2}{|c|}{ All-factors } \\
\hline & & A1B & & & & & & A1B & A2 & A1B & A2 & A1B & A2 \\
\hline Results for the 2020s & & & & & & & & & & & & & \\
\hline Total production (thousand mt) & $9,466,600$ & 0.03 & -0.04 & 0.54 & 0.46 & -0.36 & -0.42 & 0.00 & -0.06 & -0.04 & -0.13 & -0.45 & -0.53 \\
\hline Rainfed production (thousand mt) & $5,413,975$ & 0.09 & 0.41 & -2.30 & -1.85 & 1.68 & 2.08 & -0.07 & 0.06 & -0.11 & 0.48 & 1.54 & 2.16 \\
\hline Irrigated production (thousand $\mathrm{mt}$ ) & $4,052,625$ & -0.04 & -0.65 & 4.33 & 3.54 & -3.08 & -3.76 & 0.09 & -0.22 & 0.04 & -0.96 & -3.10 & -4.12 \\
\hline Total area (thousand ha) & $1,293,880$ & -- & -- & -- & -- & -- & -- & -- & -- & 0.04 & -0.30 & 0.04 & -0.30 \\
\hline Rainfed area (thousand ha) & 851,843 & -- & -- & -- & -- & -- & -- & -- & -- & -- & -- & -- & -- \\
\hline Irrigated area (thousand ha) & 442,036 & -- & -- & -- & -- & -- & -- & -- & -- & 0.11 & -0.88 & 0.11 & -0.88 \\
\hline Total water used $\left(\mathrm{km}^{3}\right)$ & 6,156 & -0.01 & -0.10 & 1.27 & 1.13 & -1.17 & -1.16 & 0.00 & -0.08 & -0.09 & -0.25 & -1.27 & -1.33 \\
\hline Green water used $\left(\mathrm{km}^{3}\right)$ & 4,511 & 0.03 & 0.09 & 0.21 & 0.26 & -0.07 & 0.09 & -0.04 & -0.03 & -0.18 & -0.10 & -0.30 & -0.12 \\
\hline Blue water used $\left(\mathrm{km}^{3}\right)$ & 1,645 & -0.14 & -0.64 & 4.19 & 3.51 & -4.17 & -4.59 & 0.11 & -0.21 & 0.17 & -0.65 & -3.95 & -4.64 \\
\hline Change in welfare (million USD) & -- & 1,064 & -58 & 17,027 & 15,488 & $-15,669$ & $-17,245$ & 1,053 & 174 & 1,303 & -452 & $-15,333$ & $-17,530$ \\
\hline Change in GDP (million USD) & -- & 1,064 & -57 & 17,041 & 15,503 & $-15,651$ & $-17,229$ & 1,053 & 174 & 1,304 & -451 & $-15,314$ & $-17,513$ \\
\hline Change in GDP (percentage) & -- & 0.00 & 0.00 & 0.03 & 0.03 & -0.03 & -0.03 & 0.00 & 0.00 & 0.00 & 0.00 & -0.03 & -0.04 \\
\hline Results for the 2050s & & & & & & & & & & & & & \\
\hline Total production (thousand mt) & $13,664,884$ & 0.03 & -0.09 & 2.85 & 2.74 & -2.64 & -2.46 & 0.02 & -0.13 & 0.24 & -0.09 & -2.28 & -2.38 \\
\hline Rainfed production (thousand mt) & $7,749,674$ & 1.15 & 1.14 & -1.94 & -1.93 & 1.31 & 1.39 & -0.47 & -0.38 & -0.81 & -0.35 & -0.28 & 0.09 \\
\hline Irrigated production (thousand $\mathrm{mt}$ ) & $5,915,210$ & -1.43 & -1.70 & 9.12 & 8.86 & -7.83 & -7.50 & 0.66 & 0.20 & 1.62 & 0.23 & -4.89 & -5.63 \\
\hline Total area (thousand ha) & $1,315,381$ & -- & -- & -- & -- & -- & -- & -- & -- & 0.79 & 0.28 & 0.79 & 0.28 \\
\hline Rainfed area (thousand ha) & 851,036 & -- & -- & -- & -- & -- & -- & -- & -- & -- & -- & -- & -- \\
\hline Irrigated area (thousand ha) & 464,345 & -- & -- & -- & -- & -- & -- & -- & -- & 2.25 & 0.79 & 2.25 & 0.79 \\
\hline Total water used $\left(\mathrm{km}^{3}\right)$ & 8,068 & 0.21 & 0.10 & 4.30 & 4.19 & -2.81 & -2.44 & 0.50 & 0.22 & 0.77 & 0.26 & -2.19 & -2.31 \\
\hline Green water used $\left(\mathrm{km}^{3}\right)$ & 5,910 & 1.00 & 0.85 & 3.05 & 2.91 & -0.72 & -0.44 & 0.55 & 0.28 & 0.52 & 0.17 & -1.04 & -1.10 \\
\hline Blue water used $\left(\mathrm{km}^{3}\right)$ & 2,158 & -1.97 & -1.95 & 7.70 & 7.69 & -8.53 & -7.91 & 0.35 & 0.06 & 1.43 & 0.51 & -5.33 & -5.64 \\
\hline Change in welfare (million USD) & -- & $-32,189$ & $-35,220$ & 191,633 & 190,634 & $-327,288$ & $-310,173$ & $-16,771$ & $-15,752$ & $-6,641$ & $-14,542$ & $-282,929$ & $-268,788$ \\
\hline Change in GDP (million USD) & -- & $-31,956$ & $-34,958$ & 193,057 & 192,083 & $-322,895$ & $-306,087$ & $-16,684$ & $-15,688$ & $-6,555$ & $-14,476$ & $-279,560$ & $-265,699$ \\
\hline Change in GDP (percentage) & -- & -0.03 & -0.04 & 0.20 & 0.20 & -0.33 & -0.32 & -0.02 & -0.02 & -0.01 & -0.01 & -0.29 & -0.28 \\
\hline
\end{tabular}




\section{Annex A:}

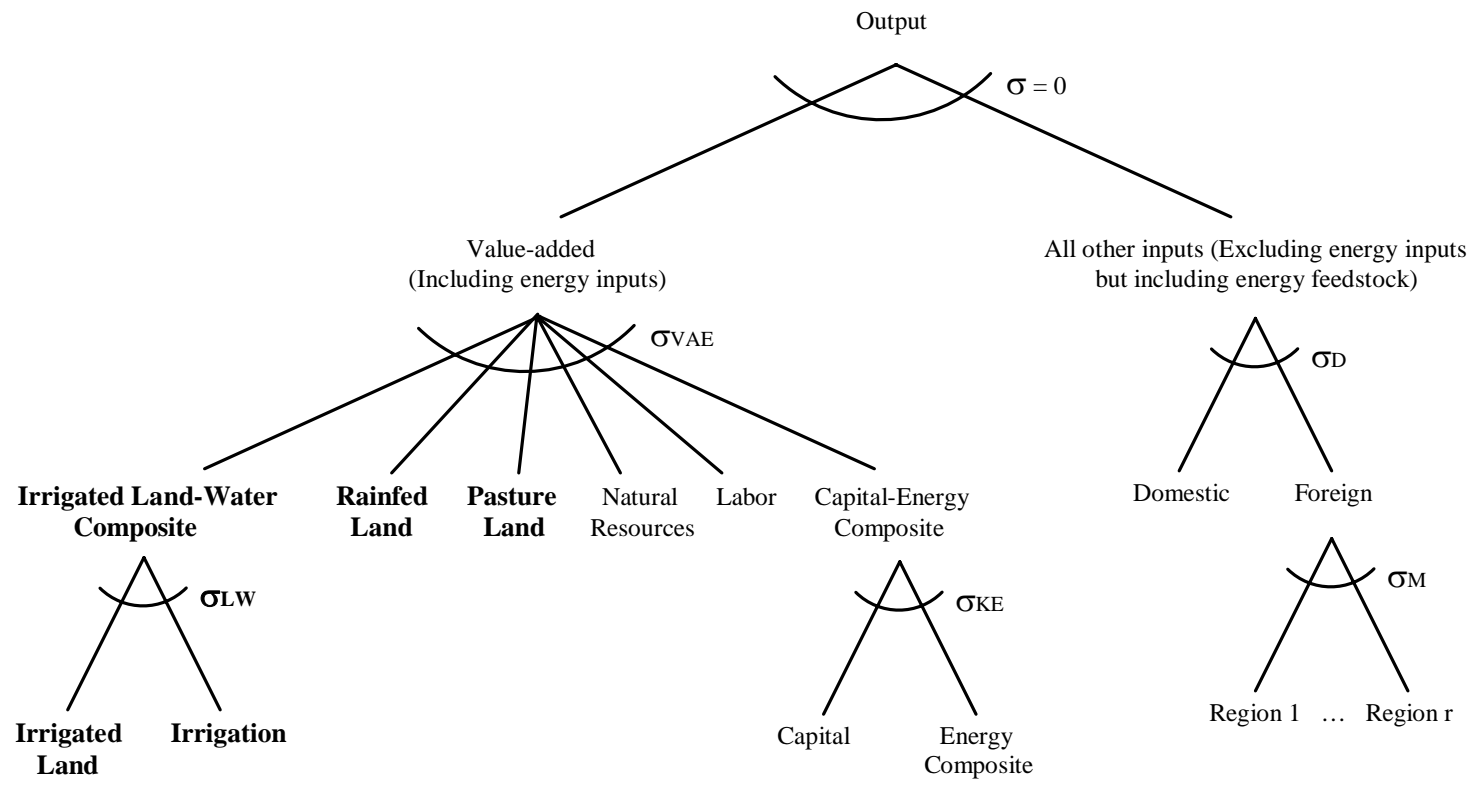

Figure A1. Nested tree structure for industrial production process in GTAP-W (truncated)

Note: The original land endowment has been split into pasture land, rainfed land, irrigated land and irrigation (bold letters). $\sigma$ is the elasticity of substitution between value added and intermediate inputs, $\sigma$ VAE is the elasticity of substitution between primary factors, $\sigma_{\mathrm{LW}}$ is the elasticity of substitution between irrigated land and irrigation, $\sigma_{K E}$ is the elasticity of substitution between capital and the energy composite, $\sigma_{D}$ is the elasticity of substitution between domestic and imported inputs and $\sigma_{\mathrm{M}}$ is the elasticity of substitution between imported inputs. 
Table A1. Aggregations in GTAP-W
A. Regional Aggregation
B. Sectoral Aggregation
1. USA - United States
1. Rice - Rice
2. CAN - Canada
2. Wheat - Wheat
3. WEU - Western Europe
3. CerCrops - Cereal grains (maize, millet,
4. JPK - Japan and South Korea sorghum and other grains)
5. ANZ - Australia and New Zealand
4. VegFruits - Vegetable, fruits, nuts
6. EEU - Eastern Europe
5. OilSeeds - Oil seeds
7. FSU - Former Soviet Union
6. Sug_Can - Sugar cane, sugar beet
8. MDE - Middle East
7. Oth_Agr - Other agricultural products
9. CAM - Central America
8. Animals - Animals
10. SAM - South America
9. Meat - Meat
11. SAS - South Asia
10. Food_Prod - Food products
12. SEA - Southeast Asia
11. Forestry - Forestry
13. CHI - China
12. Fishing - Fishing
14. NAF - North Africa
13. Coal - Coal
15. SSA - Sub-Saharan Africa
14. Oil - Oil
16. ROW - Rest of the World
15. Gas - Gas
16. Oil_Pcts - Oil products
C. Endowments
17. Electricity - Electricity
Wtr - Irrigation
18. Water - Water
Lnd - Irrigated land
19. En_Int_Ind - Energy intensive industries
RfLand - Rainfed land
20. Oth_Ind - Other industry and services
PsLand - Pasture land
21. Mserv - Market services
Lab - Labour
22. NMServ - Non-market services
Capital - Capital
NatlRes - Natural resources 


\section{Annex B:}

Table B1. 2000 baseline data: Crop harvested area and production by region and crop

\begin{tabular}{|c|c|c|c|c|c|c|c|c|}
\hline Description & $\begin{array}{c}\text { Rainfed A } \\
\text { Area } \\
\text { (thousand ha) }\end{array}$ & $\begin{array}{l}\text { gricultural } \\
\text { Production } \\
\text { (thousand mt) }\end{array}$ & $\begin{array}{c}\text { Irrigated } \\
\text { Area } \\
\text { (thousand ha) } \\
\end{array}$ & $\begin{array}{l}\text { gricultural } \\
\text { Production } \\
\text { (thousand mt) }\end{array}$ & $\begin{array}{c}\text { Area } \\
\text { (thousand ha) } \\
\end{array}$ & $\begin{array}{l}\text { tal } \\
\text { Production } \\
\text { (thousand mt) }\end{array}$ & \multicolumn{2}{|c|}{$\begin{array}{l}\text { Share of irrigated } \\
\text { agriculture in total }\end{array}$} \\
\hline Regions (total, all crops) & & & & & & & & \\
\hline United States & 35,391 & 209,833 & 67,112 & 440,470 & 102,503 & 650,303 & 65.5 & 67.7 \\
\hline Canada & 27,267 & 65,253 & 717 & 6,065 & 27,984 & 71,318 & 2.6 & 8.5 \\
\hline Western Europe & 59,494 & 462,341 & 10,130 & 146,768 & 69,624 & 609,108 & 14.5 & 24.1 \\
\hline Japan and South Korea & 1,553 & 23,080 & 4,909 & 71,056 & 6,462 & 94,136 & 76.0 & 75.5 \\
\hline Australia and New Zealand & 21,196 & 67,204 & 2,237 & 27,353 & 23,433 & 94,557 & 9.5 & 28.9 \\
\hline Eastern Europe & 37,977 & 187,468 & 5,958 & 40,470 & 43,935 & 227,939 & 13.6 & 17.8 \\
\hline Former Soviet Union & 85,794 & 235,095 & 16,793 & 74,762 & 102,587 & 309,857 & 16.4 & 24.1 \\
\hline Middle East & 29,839 & 135,151 & 21,450 & 118,989 & 51,289 & 254,140 & 41.8 & 46.8 \\
\hline Central America & 12,970 & 111,615 & 8,745 & 89,637 & 21,715 & 201,252 & 40.3 & 44.5 \\
\hline South America & 79,244 & 649,419 & 9,897 & 184,304 & 89,141 & 833,723 & 11.1 & 22.1 \\
\hline South Asia & 137,533 & 491,527 & 114,425 & 560,349 & 251,958 & $1,051,877$ & 45.4 & 53.3 \\
\hline Southeast Asia & 69,135 & 331,698 & 27,336 & 191,846 & 96,471 & 523,543 & 28.3 & 36.6 \\
\hline China & 64,236 & 615,196 & 123,018 & 907,302 & 187,254 & $1,522,498$ & 65.7 & 59.6 \\
\hline North Africa & 15,587 & 51,056 & 7,352 & 78,787 & 22,938 & 129,843 & 32.0 & 60.7 \\
\hline Sub-Saharan Africa & 171,356 & 439,492 & 5,994 & 43,283 & 177,349 & 482,775 & 3.4 & 9.0 \\
\hline Rest of the World & 3,810 & 47,466 & 1,093 & 23,931 & 4,903 & 71,397 & 22.3 & 33.5 \\
\hline World & 852,381 & $4,122,894$ & 427,164 & $3,005,371$ & $1,279,545$ & $7,128,265$ & 33.4 & 42.2 \\
\hline Crops (total, all regions) & & & & & & & & \\
\hline Rice & 59,678 & 108,179 & 93,053 & 294,934 & 152,730 & 403,113 & 60.9 & 73.2 \\
\hline Wheat & 124,147 & 303,638 & 90,492 & 285,080 & 214,639 & 588,718 & 42.2 & 48.4 \\
\hline Cereal grains & 225,603 & 504,028 & 69,402 & 369,526 & 295,005 & 873,554 & 23.5 & 42.3 \\
\hline Vegetables, fruits, nuts & 133,756 & $1,374,128$ & 36,275 & 537,730 & 170,031 & $1,911,858$ & 21.3 & 28.1 \\
\hline Oil seeds & 68,847 & 125,480 & 29,578 & 73,898 & 98,425 & 199,379 & 30.1 & 37.1 \\
\hline Sugar cane, sugar beet & 16,457 & 846,137 & 9,241 & 664,023 & 25,699 & $1,510,161$ & 36.0 & 44.0 \\
\hline Other agricultural products & 223,894 & 861,303 & 99,122 & 780,180 & 323,017 & $1,641,483$ & 30.7 & 47.5 \\
\hline Total & 852,381 & $4,122,894$ & 427,164 & $3,005,371$ & $1,279,545$ & $7,128,265$ & 33.4 & 42.2 \\
\hline
\end{tabular}

Note: 2000 data are three-year averages for 1999-2001.

Source: IMPACT, 2000 baseline data (April 2008). 
Table B2. 2020 no climate change simulation: Crop harvested area and production by region and crop

\begin{tabular}{|c|c|c|c|c|c|c|c|c|}
\hline \multirow{2}{*}{ Description } & \multicolumn{2}{|c|}{ Rainfed Agricultural } & \multicolumn{2}{|c|}{ Irrigated Agricultural } & \multicolumn{2}{|c|}{ Total } & \multicolumn{2}{|c|}{$\begin{array}{l}\text { Share of irrigated } \\
\text { agriculture in total }\end{array}$} \\
\hline & (thousand ha) & (thousand mt) & (thousand ha) & (thousand mt) & (thousand ha) & (thousand mt) & Area (\%) & Production (\%) \\
\hline Regions (total, all crops) & & & & & & & & \\
\hline United States & 33,927 & 267,740 & 68,072 & 606,204 & 101,999 & 873,944 & 66.7 & 69.4 \\
\hline Canada & 25,091 & 81,239 & 678 & 7,460 & 25,769 & 88,699 & 2.6 & 8.4 \\
\hline Western Europe & 51,622 & 472,176 & 9,391 & 166,310 & 61,013 & 638,485 & 15.4 & 26.0 \\
\hline Japan and South Korea & 1,375 & 25,068 & 4,453 & 72,230 & 5,828 & 97,299 & 76.4 & 74.2 \\
\hline Australia and New Zealand & 20,698 & 83,292 & 2,216 & 35,441 & 22,915 & 118,733 & 9.7 & 29.8 \\
\hline Eastern Europe & 34,492 & 210,311 & 5,520 & 53,325 & 40,012 & 263,636 & 13.8 & 20.2 \\
\hline Former Soviet Union & 83,591 & 309,682 & 16,838 & 100,534 & 100,430 & 410,215 & 16.8 & 24.5 \\
\hline Middle East & 30,232 & 163,563 & 22,561 & 176,977 & 52,793 & 340,539 & 42.7 & 52.0 \\
\hline Central America & 13,152 & 163,265 & 9,383 & 136,479 & 22,535 & 299,744 & 41.6 & 45.5 \\
\hline South America & 87,571 & $1,152,723$ & 11,360 & 344,208 & 98,931 & $1,496,931$ & 11.5 & 23.0 \\
\hline South Asia & 121,508 & 551,783 & 126,468 & 822,052 & 247,977 & $1,373,835$ & 51.0 & 59.8 \\
\hline Southeast Asia & 72,405 & 431,084 & 27,457 & 282,402 & 99,863 & 713,486 & 27.5 & 39.6 \\
\hline China & 61,761 & 691,581 & 120,838 & $1,014,241$ & 182,600 & $1,705,822$ & 66.2 & 59.5 \\
\hline North Africa & 16,011 & 73,390 & 7,726 & 106,969 & 23,737 & 180,359 & 32.5 & 59.3 \\
\hline Sub-Saharan Africa & 194,346 & 665,335 & 7,847 & 85,687 & 202,193 & 751,022 & 3.9 & 11.4 \\
\hline Rest of the World & 4,060 & 71,744 & 1,227 & 42,107 & 5,287 & 113,851 & 23.2 & 37.0 \\
\hline Total & 851,843 & $5,413,975$ & 442,036 & $4,052,625$ & $1,293,880$ & $9,466,600$ & 34.2 & 42.8 \\
\hline Crops (total, all regions) & & & & & & & & \\
\hline Rice & 53,799 & 107,477 & 91,696 & 327,822 & 145,495 & 435,299 & 63.0 & 75.3 \\
\hline Wheat & 117,231 & 358,153 & 89,017 & 375,312 & 206,248 & 733,466 & 43.2 & 51.2 \\
\hline Cereal grains & 222,513 & 646,828 & 73,584 & 524,949 & 296,097 & $1,171,777$ & 24.9 & 44.8 \\
\hline Vegetables, fruits, nuts & 140,559 & $1,742,380$ & 40,067 & 748,817 & 180,625 & $2,491,196$ & 22.2 & 30.1 \\
\hline Oil seeds & 70,829 & 135,312 & 30,504 & 94,146 & 101,333 & 229,458 & 30.1 & 41.0 \\
\hline Sugar cane, sugar beet & 20,753 & $1,473,872$ & 11,446 & $1,080,858$ & 32,198 & $2,554,730$ & 35.5 & 42.3 \\
\hline Other agricultural products & 226,160 & 949,953 & 105,723 & 900,721 & 331,883 & $1,850,674$ & 31.9 & 48.7 \\
\hline Total & 851,843 & $5,413,975$ & 442,036 & $4,052,625$ & $1,293,880$ & $9,466,600$ & 34.2 & 42.8 \\
\hline
\end{tabular}

Note: Linear interpolation between 2000 baseline data and 2050 simulation without climate change.

Source: IMPACT. 
Table B3. 2050 no climate change simulation: Crop harvested area and production by region and crop

\begin{tabular}{|c|c|c|c|c|c|c|c|c|}
\hline \multirow{2}{*}{ Description } & \multicolumn{2}{|c|}{ Rainfed Agricultural } & \multicolumn{2}{|c|}{ Irrigated Agricultural } & \multicolumn{2}{|c|}{ Total } & \multicolumn{2}{|c|}{$\begin{array}{l}\text { Share of irrigated } \\
\text { agriculture in total }\end{array}$} \\
\hline & (thousand ha) & (thousand mt) & (thousand ha) & (thousand mt) & (thousand ha) & (thousand mt) & Area (\%) & Production (\%) \\
\hline Regions (total all crops) & & & & & & & & \\
\hline United States & 31,731 & 359,608 & 69,511 & 872,566 & 101,243 & $1,232,174$ & 68.7 & 70.8 \\
\hline Canada & 21,827 & 97,335 & 620 & 9,640 & 22,447 & 106,975 & 2.8 & 9.0 \\
\hline Western Europe & 39,815 & 452,254 & 8,282 & 188,597 & 48,097 & 640,851 & 17.2 & 29.4 \\
\hline Japan and South Korea & 1,107 & 27,348 & 3,770 & 72,337 & 4,876 & 99,685 & 77.3 & 72.6 \\
\hline Australia and New Zealand & 19,952 & 109,152 & 2,186 & 49,047 & 22,137 & 158,200 & 9.9 & 31.0 \\
\hline Eastern Europe & 29,264 & 232,260 & 4,864 & 69,807 & 34,127 & 302,068 & 14.3 & 23.1 \\
\hline Former Soviet Union & 80,287 & 412,791 & 16,906 & 142,725 & 97,194 & 555,515 & 17.4 & 25.7 \\
\hline Middle East & 30,822 & 210,882 & 24,227 & 279,714 & 55,049 & 490,596 & 44.0 & 57.0 \\
\hline Central America & 13,425 & 259,733 & 10,341 & 221,277 & 23,766 & 481,010 & 43.5 & 46.0 \\
\hline South America & 100,062 & $2,230,050$ & 13,553 & 675,050 & 113,615 & $2,905,101$ & 11.9 & 23.2 \\
\hline South Asia & 97,471 & 645,050 & 144,534 & $1,287,136$ & 242,005 & $1,932,186$ & 59.7 & 66.6 \\
\hline Southeast Asia & 77,311 & 602,597 & 27,640 & 451,659 & 104,951 & $1,054,256$ & 26.3 & 42.8 \\
\hline China & 58,049 & 808,747 & 117,569 & $1,183,716$ & 175,619 & $1,992,463$ & 66.9 & 59.4 \\
\hline North Africa & 16,647 & 113,839 & 8,288 & 159,094 & 24,935 & 272,933 & 33.2 & 58.3 \\
\hline Sub-Saharan Africa & 228,831 & $1,070,839$ & 10,628 & 174,781 & 239,459 & $1,245,619$ & 4.4 & 14.0 \\
\hline Rest of the World & 4,435 & 117,189 & 1,427 & 78,062 & 5,862 & 195,251 & 24.3 & 40.0 \\
\hline Total & 851,036 & $7,749,674$ & 464,345 & $5,915,210$ & $1,315,381$ & $13,664,884$ & 35.3 & 43.3 \\
\hline Crops (total, all regions) & & & & & & & & \\
\hline Rice & 44,981 & 105,044 & 89,661 & 373,142 & 134,642 & 478,186 & 66.6 & 78.0 \\
\hline Wheat & 106,856 & 427,710 & 86,806 & 500,301 & 193,662 & 928,011 & 44.8 & 53.9 \\
\hline Cereal grains & 217,878 & 860,509 & 79,858 & 788,785 & 297,735 & $1,649,294$ & 26.8 & 47.8 \\
\hline Vegetables, fruits, nuts & 150,763 & $2,346,842$ & 45,754 & $1,124,570$ & 196,517 & $3,471,412$ & 23.3 & 32.4 \\
\hline Oil seeds & 73,803 & 148,761 & 31,892 & 127,020 & 105,696 & 275,782 & 30.2 & 46.1 \\
\hline Sugar cane, sugar beet & 27,197 & $2,799,190$ & 14,752 & $1,914,327$ & 41,948 & $4,713,517$ & 35.2 & 40.6 \\
\hline Other agricultural products & 229,558 & $1,061,618$ & 115,623 & $1,087,064$ & 345,182 & $2,148,682$ & 33.5 & 50.6 \\
\hline Total & 851,036 & $7,749,674$ & 464,345 & $5,915,210$ & 1,315,381 & $13,664,884$ & 35.3 & 43.3 \\
\hline
\end{tabular}

Source: IMPACT, 2050 simulation without climate change (April 2008). 
Table B4. Crop yield responses to changes in precipitation and temperature by crop type

\begin{tabular}{|c|c|c|c|c|c|c|c|c|}
\hline \multirow{3}{*}{ Regions } & \multicolumn{4}{|c|}{ Precipitation } & \multicolumn{4}{|c|}{ Temperature } \\
\hline & \multicolumn{2}{|c|}{$-20 \%$} & \multicolumn{2}{|c|}{$+20 \%$} & \multicolumn{2}{|c|}{$+2^{\circ} \mathrm{C}$} & \multicolumn{2}{|c|}{$+4^{\circ} \mathrm{C}$} \\
\hline & C3 crops & C4 crops & C3 crops & C4 crops & C3 crops & C4 crops & C3 crops & C4 crops \\
\hline United States & -17.83 & -13.00 & 12.50 & 7.33 & -18.67 & -10.67 & -34.00 & -20.33 \\
\hline Canada & -31.00 & -31.00 & 26.14 & 26.14 & -21.14 & -21.14 & -37.14 & -37.14 \\
\hline Western Europe & -7.27 & 5.49 & 4.58 & 0.60 & -4.06 & -1.06 & -12.71 & -9.82 \\
\hline Japan and South Korea & -7.50 & -7.50 & 3.67 & 3.67 & -10.33 & -4.50 & -18.00 & -17.83 \\
\hline Australia and New Zealand & -37.65 & -37.65 & 29.02 & 29.02 & 10.59 & 10.59 & -1.57 & -1.57 \\
\hline Eastern Europe & -7.27 & 5.49 & 4.58 & 0.60 & -4.06 & -1.06 & -12.71 & -9.82 \\
\hline Former Soviet Union & -12.50 & -12.50 & 7.00 & 7.00 & -21.50 & -21.50 & -39.00 & -39.00 \\
\hline Middle East & -37.65 & -37.65 & 29.02 & 29.02 & -17.29 & -13.03 & -29.32 & -24.95 \\
\hline Central America & -3.46 & -3.77 & 2.10 & 2.52 & -13.93 & -8.81 & -29.08 & -18.87 \\
\hline South America & -3.62 & -0.26 & 2.44 & -1.01 & -14.57 & -10.37 & -30.20 & -19.83 \\
\hline South Asia & 1.67 & 1.67 & 11.11 & 11.11 & -16.38 & -16.38 & -30.49 & -30.49 \\
\hline Southeast Asia & 1.67 & 1.67 & 11.11 & 11.11 & -23.71 & -23.71 & -43.60 & -43.60 \\
\hline China & -7.50 & -2.00 & 5.00 & 1.00 & -0.67 & -7.00 & -7.33 & -17.00 \\
\hline North Africa & -37.65 & -37.65 & 29.02 & 29.02 & -17.29 & -13.03 & -29.32 & -24.95 \\
\hline Sub-Saharan Africa & -3.62 & -0.26 & 2.44 & -1.01 & -10.91 & -10.91 & -25.40 & -25.40 \\
\hline Rest of the World & -3.46 & -3.77 & 2.10 & 2.52 & -13.93 & -8.81 & -29.08 & -18.87 \\
\hline
\end{tabular}

Source: Based on Rosenzweig and Iglesias (1994) and Jin and Zhu (2008).

Note: In GTAP-W, rice, wheat, vegetables, fruits, nuts, oil seeds and other agricultural products are considered C3 crops. Cereal grains, sugar cane and sugar beet are considered C4 crops. 